\title{
Job creation and trade in manufactures: industry-level analysis across countries
}

Admasu Shiferaw ${ }^{1 *}$ and Degol Hailu ${ }^{2}$

\author{
* Correspondence: ashiferaw@wm. \\ edu \\ ${ }^{1}$ The College of William and Mary \\ Williamsburg, Virginia, USA \\ Full list of author information is \\ available at the end of the article
}

\begin{abstract}
This paper examines industry-level responses of manufacturing employment in the context of globalization using a large sample of developed, developing, and transition economies. We find that developing countries need atypically high rates of value-added growth (about $10 \%$ ) to increase manufacturing employment appreciably (about $4 \%$ ). The employment benefits of export orientation are also modest even in "comparative advantage" industries of developing countries. However, diversifying the export basket contributes significantly to employment growth, particularly in the medium- and high-technology industries. Import competition does not undermine employment growth in low-technology industries of developing countries while it displaces jobs in the same industries in Organisation for Economic Co-operation and Development (OECD) and transition economies. For developing countries, import-induced job losses are higher in the more capitalintensive medium-technology industries. Jobs in high-technology industries are less sensitive to imports with positive relationships observed in the OECD. Investment also complements job creation in low-technology industries of developing countries that have yet to industrialize.
\end{abstract}

JEL codes: J21, L60, O14, O25

Keywords: Labor demand, Employment elasticity, Manufacturing, Export orientation, Import competition

\section{Introduction}

Economic development and poverty reduction in developing countries depend critically on access to gainful job opportunities. The World Bank's 2013 World Development Report highlighted the broader socioeconomic significance of jobs that transcend the private returns to employment (World Bank 2012). Employment in formal sector manufacturing, the focus of this paper, receives special attention from policymakers and researchers partly because it provides relatively stable and better paying jobs. Such desirable attributes of jobs deserve emphasis as the bulk of employment opportunities in developing countries are created by small firms in the unregistered sector where earnings are typically unsteady and job-related benefits are nonexistent (World Bank 2012; Goldberg and Pavcnik 2003).

While a number of studies underscore the critical role of industrial progress and diversification for economic growth (Hausmann et al. 2007; Jones and Olken 2005; Imbs and Wacziarg 2003), the labor market implications of industrialization and diversification are

(c) 2016 Shiferaw and Hailu. Open Access This article is distributed under the terms of the Creative Commons Attribution 4.0 International License (http://creativecommons.org/licenses/by/4.0/), which permits unrestricted use, distribution, and reproduction in any medium, provided you give appropriate credit to the original author(s) and the source, provide a link to the Creative Commons license, and indicate if changes were made. 
not entirely clear partly because such processes are taking place in the context of increasingly globalized economies. Uncertainty about employment prospects also arises from recent episodes of "job-less" economic growth experienced by both developed and developing countries at least in the short to medium runs (Caballero and Hammour 1997; Kapsos 2005). In fact, many developing countries grapple with persistently high unemployment rates, especially in urban areas, in spite of more open and growing economies. Overcoming constraints to economic growth and exports therefore does not seem to guarantee satisfactory labor market outcomes. A recent review of empirical studies from semi-industrialized developing countries by Goldberg and Pavcnik (2007) shows that trade liberalization has been accompanied by rising wage inequality contrary to the expectation of more favorable outcomes for low-skilled workers. Evidence is still lacking on the more pressing issue of unemployment and global integration particularly in developing countries. The limited empirical literature coming mainly from developed countries provides a mixed picture on the employment effects of trade liberalization as discussed later in this paper.

Labor economists assert that strict labor market regulations are among the main culprits for slow employment growth (Botero et al. 2004; Haltiwanger et al. 2008). The assumption is that employers respond to restrictive hiring and firing regulations with lackluster job creation, investing instead on productivity enhancing activities (Caballero and Hammour 1997). However, Freeman (2010) and World Bank (2012) report only modest, if any, impacts of labor market regulations in developing countries partly because of weak enforcement of regulations. ${ }^{1}$ Concurrent with trade liberalization, most developing countries have also been relaxing labor laws during the 1990s (Goldberg and Pavcnik 2007) further attenuating the potential explanatory power of labor market institutions.

Over the last decade or so, economists began to explore firm heterogeneity in size, productivity, and export orientation to better understand the mechanisms through which trade openness may affect labor market outcomes. More recent trade theories extend the Meltitz (2003) model with heterogeneous firms by introducing labor market imperfections arising not as such from hiring and firing regulations but from search frictions, efficiency wages, or firm-specific wage bargaining. Leading contributions in this regard include Egger and Kreickemeier (2009), Helpman et al. (2010), Felbermayr et al. (2011a), and Davis and Harrigan (2011). These new models highlight the conditions under which trade openness could increase wage inequality and the unemployment rate. This marks a significant improvement over comparative advantage and intra-industry trade models whose implications often do not match observed labor market outcomes.

While the abovementioned theoretical contributions inspire the empirical analysis in this paper, some of their restrictive features need to be addressed. For instance, potential differences in the labor market effects of trade for developed and developing countries are often ignored mainly because of the focus on intra-industry trade among countries with similar economic structures. ${ }^{2}$ Similarly, variation in industry-level responses to trade reforms cannot be inferred directly from the latest trade models given their emphasis on equilibrium unemployment rate and wage inequality. However, the controversies surrounding trade liberalization arise primarily from divergences in economic structure and patterns of specialization across countries. The empirical approach in this paper therefore addresses such differences by using industry-level analysis of employment for countries with dissimilar economic structures. As compared to the large empirical literature on the 
productivity and wage inequality effects of globalization, studies that address its employment effects are rare and differ remarkably on a number of dimensions. These include differences in response variables, levels of aggregation, measures of trade openness, and data sources and quality, which complicate meaningful comparison of the existing evidence and the lessons to be drawn.

This paper contributes to this literature by estimating a labor demand model for a large sample of developing, transition, and developed countries observed over the period 19902009. The model examines industry-level responses of manufacturing employment to changes in market demand, factor prices, and trade openness as well as investment and export basket diversification. We use four-digit International Standard Industrial Classification (ISIC) industries that are matched with trade flows from 72 countries. The analysis allows model parameters to vary across regional labor markets and industry categories at different level of technological advancement. We also use country- and industry-specific instrumental variables to address endogeneity problems that often undermine estimation of labor demand models.

As a preview of our results, we find a negative wage elasticity of labor demand that tends to decline in industries with relatively high labor share of output. Growth in demand increases manufacturing employment although the elasticity is far less proportionate such that developing countries may need to achieve atypically high rates of valueadded growth (about $10 \%$ ) to increase employment by about $4 \%$. While demand and own-price elasticities of labor demand are remarkably similar across all countries and industries, systematic regional differences emerge in the labor market implications of trade openness. The employment response to trade openness also depends crucially on the technological composition of industries. Export orientation has at best modest employment benefits even in "comparative-advantage" industries of developing countries, while it tends to slowdown job destruction in low-technology industries of Organisation for Economic Co-operation and Development (OECD) countries. However, we did not find employment reducing effects of exports as implied by recent trade theories. Import penetration does not reduce employment growth in low-technology industries of developing countries while it leads to substantial job displacement in the same industries in the OECD. For developing countries, import-induced job losses are relatively high in the more capital-intensive medium-technology industries. Diversification of the export basket boosts job creation particularly in skill-intensive industries of both developed and developing countries. For countries that have yet to industrialize and become accomplished exporters of manufactures, investment has a strong complementary effect on employment.

The rest of the paper is organized as follows: Section 2 outlines the theoretical perspectives that inspire our labor demand model and provides a review of existing empirical evidence. Section 3 discusses the datasets and describes the distribution of key variables as well as the industrial composition of employment and trade. Estimation issues and instruments are addressed in Section 4 while Section 5 discusses the results. Section 6 provides estimates for an extended labor demand model while Section 7 concludes the paper with some policy implications.

\section{Theoretical framework}

We draw both on theories of labor demand and international trade to assess manufacturing employment in the context of globalization. 


\subsection{Derived demand for labor}

Following Hamermesh (1993), the own-price elasticity of labor demand holding output constant can be expressed as:

$$
\eta_{L L}=\frac{\partial \ln L}{\partial \ln w}=-\left[1-S_{L}\right] \sigma
$$

where $L$ is labor and $w$ is wage rate, $\sigma$ is the elasticity of substitution between labor and other inputs, and $S_{L}$ is the revenue share of labor. Since wage shocks affect product prices, the resulting adjustment in the scale of production will also affect labor demand. Hamermesh (1993) shows this effect to depend on the price elasticity of consumer demand $\eta$. Therefore, the total own-price elasticity of labor demand can be expressed as:

$$
\eta_{L L}=-\left[1-S_{L}\right] \sigma-S_{L} \eta
$$

Equation (2) shows a negative wage elasticity of labor demand with two components: the "substitution effect" represented by $\left[1-S_{L}\right] \sigma$ and the "scale effect" represented by $S_{L} \eta$ (Slaughter 2001). In an industry with low labor share, wage spikes affect labor demand primarily through the factor substitution effect while the scale effect dominates in industries with relatively high labor share.

Our basic labor demand function, following Hamermesh's log-linear specification can thus be expressed as:

$$
\ln \left(L_{j t}\right)=\delta+\beta \ln \left(V_{j t}\right)+\alpha \ln \left(w_{j t}\right)+\varepsilon_{j t}
$$

where $L$ stands for units of labor, $V$ is value added, $w$ is wage rate, $j$ indexes industry, and $t$ indexes time.

In assessing the effect of trade openness on labor demand, Rodrik (1997) argues that imports not only push the price index down but also raise the price elasticity of demand ( $\eta$ ) as access to a wide variety of consumer goods increases. The own-price elasticity of labor demand will thus increase in import competing industries. He also underscores that better access to imported intermediate inputs and parts may give domestic firms further flexibility in organizing production which implies an increase in $\sigma$ and thus higher wage elasticity of labor demand following a reduction in import restrictions. Slaughter (2001) provides further details on these mechanisms.

To better understand the net effect in a given industry with a known labor share, Eq. (2) can be rearranged as: $\eta_{L L}=-\sigma-S_{L}(\eta-\sigma)$. Therefore, in industries where $\eta>\sigma$, the ownprice elasticity of labor demand increases with $S_{L}$. Since the price elasticity of product demand is equivalent to the elasticity of substitutions between final goods (Slaughter 2001), an increase in $\eta_{L L}$ with the labor share of output implies that consumers' elasticity of substitution between products is greater than firms' elasticity of substitution between inputs. Trade liberalization can intensify this by increasing consumers' choices more than the input choices for domestic firms. However, if consumer demand is relatively price inelastic and imports primarily increases $\sigma$, then the total price elasticity of labor demand will be lower for industries with relatively high labor share.

\subsection{Trade theories and labor demand}

Recent trade theories with heterogeneous firms highlight labor market effects of trade openness other than through greater own-price elasticity of labor demand. The basis for 
this argument is the recognition that firms participating in export markets are typically larger and more efficient than firms producing only for domestic markets (Bernard et al. 2003; Bernard and Jensen 1999). Formalizing these observations, the Melitz (2003) trade model shows that the selection of exporters from the upper end of the firm size and productivity distributions intensifies the reallocation of jobs toward more productive firms. Such job churning, however, leaves equilibrium wages and unemployment intact because of the assumption of perfectly competitive labor markets in the Melitz (2003) model. The innovation of recent trade theories is thus to introduce labor market imperfection in Melitz-type models to assess trade-related wage inequality and unemployment.

Helpman et al. (2010) propose a trade model with heterogeneous firms and search frictions. Firms in this model screen workers for their abilities and large firms have economies of scale in screening allowing them to hire workers with above average abilities. Opening trade increases profits for large firms entering export markets and raises their incentive to screen workers ever more strictly. Since workers with superior abilities are difficult to replace, wages in export firms will be higher on average as compared to wages in nonexporting firms who screen less, hence increasing wage inequality after trade liberalization. Stricter screening of workers in the Helpman et al. (2010) model also reduces the hiring rate among export firms, which can increase the equilibrium unemployment rate if the vacancyto-unemployment ratio is low.

Felbermayr et al. (2011a) propose a similar model with search frictions where trade reduces the unemployment rate as long as it leads to average productivity growth. These authors argue that the value of a new job for an employer increases with average firm productivity (hence increasing the job creation rate), but productivity growth requires a reduction in variable trade costs or an increase in the number of trading partners. ${ }^{3}$

A trade model by Egger and Kreckmeire (2009) relies on workers' preference for a "fair" wage, which is tied to firm performance. Trade openness under this assumption leads to wage inequality as wages rise significantly in highly productive firms that enter into export markets. Non-export firms face stiff competition from imported final goods while experiencing pressure to keep up with high wages in export firms. Unemployment in the Egger and Kreckmeire (2009) model increases because the combined effect reduces profit margins of non-export firms forcing them to either cut jobs or exit the market. Davis and Harringa (2011) add an efficiency wage argument to a Melitz-type model where large firms pay higher than the market-clearing wage to elicit effort from their workers as it is particularly harder to monitor effort in large firms. While Davis and Harringa (2011) predict a rise in unemployment rate following trade openness, it is expected to be moderate as compared to the volume of job reallocation across firms.

Overall, the abovementioned trade models with imperfect labor markets suggest that free trade could have undesirable consequences in terms of inequality and/or unemployment despite clear welfare benefits. These predictions are quite different from both the traditional Heckscher-Ohlin-Samuelson model and the intra-industry trade models, and they seem to be more consistent with actual data and public opinion on trade. In the comparative advantage trade models, for instance, trade openness would lead to interindustry reallocation of labor (from import competing industries to export oriented ones) and reduces unemployment in a labor-abundant country. In the intra-industry trade models, countries with similar endowments can gain from trade without job reallocation across firms, as they assume no firm heterogeneity. 
The preceding discussion suggests that a labor demand model needs to account for export orientation and import competition. An increase in the revenue share of export firms could reduce employment growth as in the Helpman et al. (2010) and Davis and Harringa (2011) models, or it may lead to employment growth as in Felbermayr et al. (2011a). Since the risk of firm exit declines with firm size and productivity (Bernard and Jensen 1999), one would also expect jobs in exporter firms to be relatively more stable. It is therefore possible that as an industry gets increasingly export oriented, employment becomes more secure while job creation rates may slowdown. Although trade theories with heterogeneous firms typically assume firm productivity to be a random draw from a Pareto distribution, in practice, exporter firms would engage in long-term productivity enhancing activities such as innovation, training of workers, and investment in the latest machinery and equipment-interventions that are more frequent among large firms (Revenga 1997). The resulting productivity gains, including those from learning-through-exporting, may allow exporters to increase output with limited job creation. The effect on net employment thus becomes an empirical question.

Import competition, apart from reducing workers' bargaining power (Rodrik 1997), may lead to job destruction as in Egger and Kreckmeier (2009). However, the employment effect arguably varies across industries within a country depending on sources of competitiveness. If access to intermediate inputs is a major constraint for domestic firms, reducing import restrictions may increase average productivity. Competitive pressure could also lead to productivity growth by reducing either $x$-inefficiency or firm/worker rents (Revenga 1992). Productivity growth may thus allow domestic firms to compete effectively with imports and avoid rapid job destruction. Similar to the effects of exports on labor demand, the actual employment response to import competition is ultimately an empirical question.

The labor demand model with export orientation and import penetration at the industry level can be expressed as:

$$
\ln \left(L_{j t}\right)=\delta+\beta \ln \left(V_{j t}\right)+\alpha \ln \left(w_{j t}\right)+\phi\left(\frac{X}{Y}\right)_{j t}+\phi\left(\frac{M}{M+Y}\right)_{j t}+\varepsilon_{j t}
$$

where $X$ stands for exports, $Y$ is output, and $M$ is imports.

A detailed discussion of estimation issues will be picked up in Section 4, while we now turn to a review of related empirical studies.

\subsection{Existing empirical evidence}

The multiplicity of new trade models with different assumptions and labor market implications suggests that the unemployment effects of trade need to be assessed empirically. The empirical literature unsurprisingly shows mixed results. For a sample of industrialized countries in the OECD, Felbermayr et al. (2011b) find that trade openness, measured as the trade share of GDP, reduces the long-run unemployment rate significantly. Using a large sample of developed and developing countries, Dutt et al. (2009) also find that trade liberalization reduces the national unemployment rate in the long run although unemployment may increase in the short run. While these papers assess national unemployment rates, they say very little about industry-specific effects, which can be important given the across-country differences in industry structure. 
Studies that examine industry-level employment and trade often use data from a single country and provide interesting results. Earlier studies by Greenaway et al. (1999) for the UK, Revenga (1992) and Sachs et al. (1994) for the USA, and Revenga (1997) for Mexico all find employment reducing effects of trade openness. ${ }^{4}$ More recently, Autor et al. (2013) find that import competition from China has a significant negative effect on local labor markets in the USA. Dauth et al. (2014) find that imports from China and East Europe have a mild adverse employment effect on employment while the net employment effect of trade exposure is positive because of strong German exports to these countries. Hasan et al. (2007) investigate the effects of India's 1991 trade reform on industry-level labor demand. They find significant post-reform increases in the own-price elasticity of labor demand, which tend to be higher for Indian states with flexible labor markets. However, the coefficients on indicators of trade policy shifts are by and large insignificant. Also, using industry- and state-level data from India, Hasan et al. (2012) find that trade protection increases unemployment in states with flexible labor markets particularly in urban areas with export-oriented industries.

The evidence from Latin American countries is not as encouraging. According to Attanasio et al. (2004), trade liberalization in Colombia during the late 1980s and early 1990s significantly increased wage inequality and the likelihood of informal sector employment where wages and benefits are minimal. The argument is that formal sector firms exposed to increased import competition cut permanent employment positions and outsource some activities to low-wage workers in the informal sector. In Brazil, MenezesFilho and Muendler (2011) find large transitions of workers out of the labor force and into unemployment following trade liberalization. The authors argue that reallocation of labor to exporters and comparative-advantage sectors is not enough to accommodate importinduced job displacements from the formal sector. Both Attanasio et al. (2004) and Menezes-Filho and Muendler (2011) use household surveys to match workers with their industrial affiliation, and it will be interesting to examine the evidence based on actual industry-level data as we do latter in this paper. There is now a large literature on the productivity effects of trade liberalization in developing countries. ${ }^{5}$

Studies on African countries are rather scarce and focus on South Africa. Using industry-level data, Jenkins (2008) shows that both imports and exports have negative effects on labor demand in South African manufacturing while Johnson and Subramanian (2001) show that tariff reductions increase productivity growth. Firm-level evidence by Söderbom and Teal (2000) show that exporter firms in Africa are larger, more productive, and capital intensive on average than firms supplying only to domestic markets.

The empirical evidence on unemployment effects of trade liberalization is thus quite mixed although the weight of evidence leans slightly toward the unemployment increasing effect. Such mixed results are unsurprising given the wide variation across studies in terms of dependent variables, indicators of trade openness, model specification, estimation methods, and time horizon. Some studies use national unemployment rates while other use state- and industry-level data. Trade measures also include indices of trade volume as well as actual trade policy changes. How much of the disparity in the existing empirical evidence reflects differences in data and methodologies is quite unknown. One of the contributions of this paper is thus to provide a consistent set of empirical evidence on the employment-trade relationship using the same data sources, level of disaggregation, model specification, and estimation method for a large sample of developing, transition, and developed countries over a comparable time horizon. The analysis also takes into 
account potential differences in the employment response to trade openness based on the technological advancement of manufacturing industries. This approach allows a better comparison of performances across countries while addressing differences in industry structure and degree of trade integration.

\section{Data and descriptive statistics}

\subsection{Data}

The paper combines two datasets on manufacturing industries. The first one is UNIDO's Industrial Statistics database (INDSTAT4) that provides disaggregated data on industrial activities at the four-digit ISIC level. INDSTAT4 reports, among other variables, the number of workers $(L)$ and current US dollar values of total output $(Y)$, value added $(V)$, the wage bill $(W)$, and investment $(I)$ in an industry. The other data source is the United Nations Commodity Trade database (COMTRADE), which provides highly disaggregated data on exports $(X)$ and imports $(M)$ at the level of six-digit Harmonized System trade classification codes (HS codes). The trade data is restricted to manufacturing industries. The two datasets are combined at the four-digit ISIC level using a concordance provided by the UN statistics division.

The response variable of interest, $\ln \left(L_{i j t}\right)$, is the logarithm of total number of workers in country $i$ and industry $j$ at time $t$. The wage rate $(w)$ in an industry represents the average wage per worker obtained by dividing the total wage bill by the total number of workers. Partial labor productivity $(v)$ is calculated as value added per worker in a four-digit ISIC industry. Constant price values of output, value added, and wages are calculated using producer price indices (PPI) for two-digit ISIC industries from INDSTAT2 database. This database provides industry-level indices of volume of output from which we were able to recover the underlying producer price index. For industries with missing values of PPI, we use the manufacturing sector PPI.

The export share of output $(X / Y)$ and import penetration rates $[M /(M+Y)]$ are calculated by using trade data from COMTRADE and total output from INDSTAT4. The number of export items (HS) refers to the number of six-digit products in a four-digit ISIC industry for which a country has nonzero exports. The number of competing countries (CX) is the number of exporting countries around the world; for each HS code, a country is an active exporter.

We have data on the abovementioned variables for 72 countries: eight from SubSaharan Africa (SSA), 11 from Asia and the Pacific (ASIA), ten from Latin American and the Caribbean (LAC), eight from Middle East and North Africa (MENA), 16 from Central and East Europe (CEE), and 19 from the OECD. The sample period extends from 1990 to 2009 with unbalanced panel at the industry level. See Appendix $C$ for the list of countries.

\subsection{Growth rates}

Table 1 provides summary statistics on manufacturing output and employment by region. Real manufacturing value added grew at about $3 \%$ per annum during $1990-2008^{6}$ for the entire sample with growth rates in developing countries exceeding that of OECD countries.

At about $3 \%$ per annum, SSA and MENA are the only regions with relatively strong employment growth during the sample period. To put growth rates in perspective, it 
Table 1 Performance of manufacturing by region (growth rates in percent) 1990-2008

\begin{tabular}{lcccccccrc}
\hline & $\Delta Y / Y$ & $\Delta V N$ & \multicolumn{1}{c}{$\Delta L / L$} & $\Delta W / W$ & $\Delta W / W$ & $\Delta v / N$ & $\ln (W)$ & $\ln (v)$ & $I / Y$ \\
\hline LAC & 2.50 & 3.26 & 0.61 & 0.79 & -0.09 & 2.39 & 8.60 & 10.16 & 0.06 \\
SSA & 4.94 & 2.98 & 3.27 & 2.99 & 0.00 & -0.01 & 7.10 & 8.48 & 0.08 \\
MENA & 6.44 & 5.70 & 3.11 & 5.74 & 3.32 & 3.28 & 8.40 & 9.59 & 0.21 \\
ASIA & 3.49 & 2.27 & 1.61 & 1.66 & 1.14 & 1.75 & 8.69 & 10.07 & 0.17 \\
CEE & 5.69 & 6.36 & -0.96 & 4.19 & 5.07 & 7.24 & 8.09 & 9.04 & 0.17 \\
OECD & 1.21 & 0.63 & -1.31 & 0.17 & 1.33 & 1.79 & 10.28 & 11.08 & 0.05 \\
Total & 3.19 & 2.91 & -0.05 & 1.88 & 2.11 & 3.14 & 9.13 & 10.17 & 0.10 \\
\hline
\end{tabular}

Source: UNIDO INDSTAT4

Note: All variables are in real values

$Y$ output, $V$ value added, $L$ employment, $W$ wage bill, $w$ wage per worker, $v$ value added per worker, $I / Y$ investment to output ratio, $\Delta$ difference

should be recognized that SSA and MENA regions started from a very low manufacturing base. Employment in semi-industrialized ASIA and LAC regions grew rather slowly at 1.6 and $0.6 \%$, respectively. The more advanced CEE and OECD countries, however, experienced absolute contraction of employment at 1 and $1.3 \%$, respectively. The regional averages suggest that growth in manufacturing employment tends to wane with the maturity and technological advancement of the sector. This is consistent with Herrendorf et al. (2013) where they find an inverted U-shape relationship between the employment share of manufacturing and per capita income.

Real wage rates in our sample grew on average by about $2 \%$ per annum during 1990 2008. Real wages in MENA and CEE increased by 3.3 and $5.1 \%$, respectively, mirroring the above average value-added growth rates in these regions shown in Table 1. In ASIA and OECD countries, real wages grew modestly just above $1 \%$ while they literally stagnated in LAC and SSA. ${ }^{7}$ This suggests that the increase in manufacturing wage bills in LAC and SSA is driven predominantly, if not entirely, by employment growth as shown in Table 1. This contrast with CEE and OECD countries where the wage bill grew entirely because of wage rates as employment declined. Not surprisingly, labor productivity and wage rates are highest in the OECD and lowest in SSA countries.

The regional aggregates in Table 1 conceal important nuances at lower levels of aggregation, which are unraveled in Table 2. For this analysis, we follow the OECD's approach for a technological classification of manufacturing industries with slightly different cutoff points. This classification as outlined in Hatzichronoglou 1997) uses the R\&D intensity of manufacturing activities for a sample of OECD countries. Accordingly, we classify the food, beverage, tobacco, textile, garments, leather, and wood industries as "low-technology" industries. These are industries that typically require standardized technologies and rely mainly on unskilled labor justifying why they have often been considered as "comparative-advantage" industries for developing countries. The printing and paper, chemical and plastic, nonmetal, and metal industries are considered to be "medium-technology" industries that are often capital-intensive and may require semi-skilled labor. The machinery, transport equipment, electronics, semiconductor, and precision instruments industries are classified as "high-technology" industries. Competitiveness in the latter often requires continuous upgrading of technologies and a critical mass of skilled labor, hence giving developed countries an edge over developing countries. ${ }^{8}$ 
Table 2 Employment and value-added growth rates by industry and region

\begin{tabular}{|c|c|c|c|c|c|c|}
\hline & \multicolumn{2}{|c|}{ Low technology } & \multicolumn{2}{|c|}{ Medium technology } & \multicolumn{2}{|c|}{ High technology } \\
\hline & 1990-1999 & $2000-2008$ & 1990-1999 & $2000-2008$ & 1990-1999 & $2000-2008$ \\
\hline \multirow[t]{2}{*}{$\overline{L A C}$} & -0.46 & 0.56 & 1.10 & 1.64 & 0.17 & 0.85 \\
\hline & 1.42 & 3.20 & -0.54 & 4.29 & -2.56 & 8.19 \\
\hline \multirow[t]{2}{*}{ SSA } & 2.40 & 2.89 & -1.75 & 5.18 & 28.53 & 8.56 \\
\hline & 6.87 & 3.64 & 4.91 & 0.65 & -3.76 & 1.54 \\
\hline \multirow[t]{2}{*}{ MENA } & 2.18 & 0.70 & 5.88 & 3.72 & 16.33 & 9.27 \\
\hline & 2.16 & 4.99 & -0.49 & 8.25 & 3.24 & 7.47 \\
\hline \multirow[t]{2}{*}{ ASIA } & -3.99 & 0.65 & 0.63 & 4.26 & 4.06 & 7.24 \\
\hline & 3.50 & 0.64 & 6.26 & 1.69 & 14.81 & 2.66 \\
\hline \multirow[t]{2}{*}{ CEE } & -2.55 & -2.94 & -2.59 & 1.24 & -5.42 & 2.96 \\
\hline & -4.87 & 6.35 & -1.00 & 10.34 & -8.90 & 7.09 \\
\hline \multirow[t]{2}{*}{ OECD } & -2.36 & -2.83 & -0.33 & -0.75 & 0.11 & 1.90 \\
\hline & 0.13 & -1.59 & 4.46 & 0.62 & 5.16 & 2.53 \\
\hline
\end{tabular}

Source: UNIDO INDSTAT4

Note: The top number in each cell is employment growth rate while the bottom number in italics is value-added growth rate

Table 2 shows that employment in ASIA's high-technology (HT) manufacturing industries expanded at 4 and $7 \%$ in the 1990s and 2000s, respectively, revealing that the slow employment growth in this region (Table 1) is due to weak job creation in low-technology (LT) industries. LT industries, on the other hand, drive employment growth in SSA while medium-technology (MT) industries have been critical in MENA countries (mainly in the petro-chemical industry). ${ }^{9}$ None of the industries in LAC show strong employment performance. Not surprisingly, the main source of decline in manufacturing employment in the OECD has been sustained job losses in LT industries. Employment in MT industries in the OECD suffered only minor contractions while HT industries actually gained employment since 2000. Therefore, Table 2 indicates an underlying job reallocation process across manufacturing industries within a region especially in ASIA and OECD countries. It also shows a rather persistent division of labor among regions that may keep the technological gap from closing.

\subsection{Structural change}

To give further insight into structural features of manufacturing, we juxtapose the employment and output compositions of industries in Fig. 1a at 5-year intervals. It is clear that the employment shares of LT industries have been increasing steadily in SSA, LAC, and MENA regions while they declined in ASIA, CEE, and OECD countries. This pattern is reversed in MT industries whose employment shares declined in SSA, LAC, and MENA countries while they increased in ASIA, CEE, and OECD countries (the trend reversing a bit in SSA during 2005-2009). While no clear trend is detectable in HT industries, the employment shares are clearly higher in ASIA, CEE, and OECD countries. Since trade openness increased during the sample period, Fig. 1a seems to suggest that international trade reinforces existing differences in industrial structure between developed and developing countries. This is quite different from Wacziarg and Wallack (2004) who find insignificant effects of trade on job reallocation across 


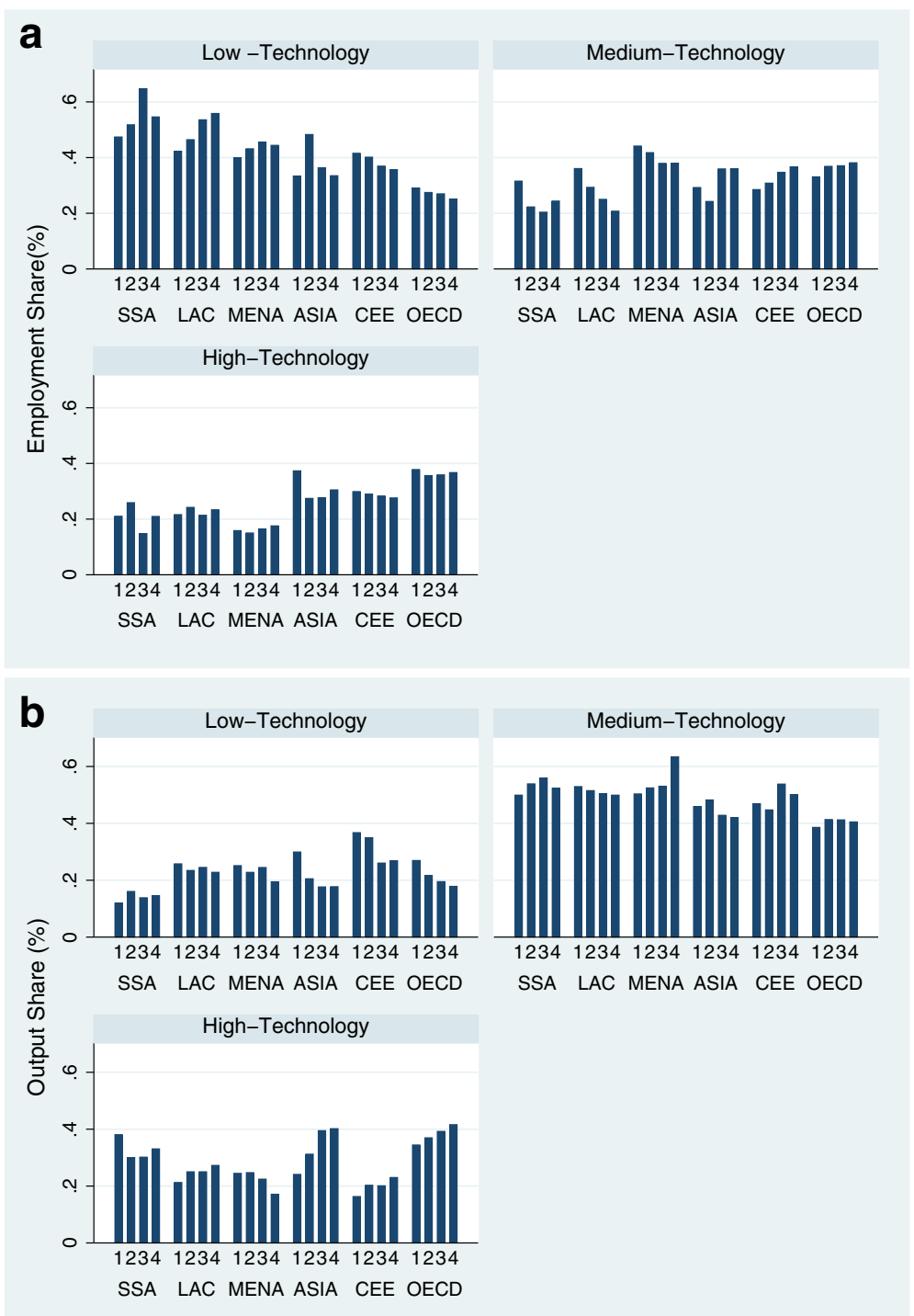

Fig. 1 a Employment share of industries by level of technology and region. $\mathbf{b}$ Output share of industries by level of technology and region. Note: Numbers 1 to 4 in both panels refer to 5-year intervals for 1990-1994, 1995-1999, 2000-2004 and 2005-2009, respectively

industries for emerging countries but quite consistent with Menezes-Filho and Muendler (2011) for Brazil.

The industrial distribution of manufacturing employment, however, does not always coincide with the distribution of output. Figure $1 \mathrm{~b}$ shows that the output shares of LT industries in SSA, LAC, and MENA are far less than their respective employment shares. Most importantly, the output shares of LT industries are not rising with the increasing employment shares in these regions suggesting a decline in labor productivity in this sector. In ASIA, CEE, and OECD countries, however, there has been a decline in the output shares of LT industries consistent with the declining trend in their employment shares. Strikingly, the output shares of MT industries are far greater than their employment shares across all regions with little variation over time underscoring their capital-intensive technologies. MT industries also dominate manufacturing output 
in the developing world with output shares more than twice that of LT industries. As would be expected, the output shares of HT industries show a steady increase over time only in ASIA, CEE, and OECD countries.

A few remarks can be made based on Fig. 1a, b:

(i) That LT industries are clearly labor intensive while MT industries tend to be capitalintensive, with HT industries standing somewhere in between.

(ii) That except for ASIA, there is less dynamics in the technological composition of manufacturing output in developing countries while employment is shifting away from MT to LT industries. Employment and output in ASIA are both shifting toward MT and HT industries similar to the patterns in CEE and OECD countries.

(iii) That the employment and output shares of industries in the OECD and CEE are rather balanced indicating equivalence of labor productivity (output per person) in LT, MT, and HT industries.

Unlike developed countries, there is stark cross-industry variation in labor productivity in developing countries suggesting ample room for reallocation of resources within the manufacturing sector.

\subsection{Trade in manufactures}

Turning to international trade, Table 3 shows that about a quarter of manufactured output in a four-digit industry is exported during 1990-2008 with noticeable differences across regions. OECD countries have the highest export orientation at $31 \%$ while SSA countries have the lowest rate at less than $7 \%$. This is consistent with the expected positive correlation between exports and productivity. Export orientation of manufacturing has increased steadily from about $14 \%$ of output during 1990-1994 to about $29 \%$ during 2005-2009 for the entire sample. At the same time, import penetration rate also increased from 14 to $25 \%$ suggesting greater trade openness. Within the developing world, LAC has the highest import penetration rate $(24 \%)$, which is at par with that of OECD countries.

Figure 2a shows export orientations that often do not reflect the underlying employment structure. Low-technology industries in ASIA, CEE, and OECD countries have become increasingly export oriented although the employment and output shares of LT

Table 3 Trade in manufactures by region (growth rates in percent) 1990-2008

\begin{tabular}{|c|c|c|c|c|c|c|c|}
\hline Region & SSA & LAC & MENA & Asia & CEE & OECD & Total \\
\hline $\ln (X)$ & 7.74 & 14.61 & 11.29 & 16.52 & 14.29 & 17.34 & 15.31 \\
\hline$\Delta X X$ & 14.74 & 13.19 & 16.61 & 12.34 & 14.63 & 5.45 & 10.41 \\
\hline$X Y$ & 0.07 & 0.19 & 0.12 & 0.22 & 0.28 & 0.31 & 0.25 \\
\hline $\ln (H S)$ & 6.18 & 7.30 & 6.01 & 6.34 & 6.67 & 6.92 & 6.75 \\
\hline $\ln (C X)$ & 4.61 & 4.03 & 4.62 & 4.46 & 4.36 & 4.27 & 4.32 \\
\hline $\ln (M)$ & 13.77 & 16.39 & 14.73 & 17.21 & 16.05 & 18.22 & 16.93 \\
\hline$\Delta M / M$ & 11.84 & 9.78 & 12.38 & 11.09 & 15.71 & 5.39 & 9.74 \\
\hline$M /(M+Y)$ & 0.16 & 0.24 & 0.15 & 0.14 & 0.29 & 0.24 & 0.23 \\
\hline
\end{tabular}

Source: UN COMTRADE

$X$ export earnings, $X / Y$ export to output ratio, $H S$ number of six-digit HS export items in a four-digit industry, $C X$ number of countries exporting the same HS code, $M$ value of imports, $M /(M+Y)$ import penetration ratio, $\Delta$ difference 


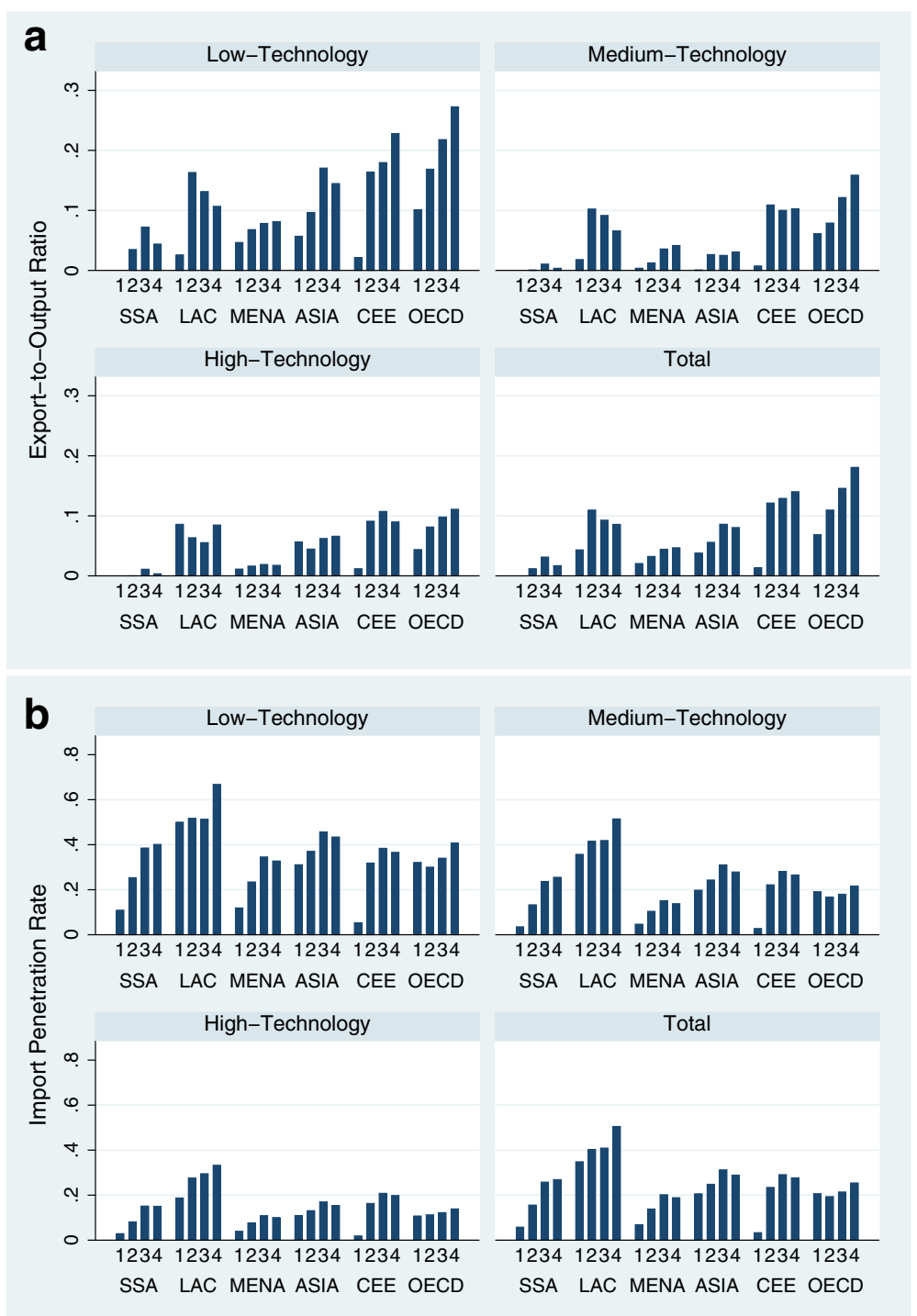

Fig. 2 a Export-output ratio by industry and region. $\mathbf{b}$ Import penetration rate by industry and region. Note: Numbers 1 to 4 in both panels refer to 5-year intervals for 1990-1994, 1995-1999, 2000-2004 and 2005-2009, respectively

industries have been declining steadily in these regions. For the rest of the developing world, export orientation of LT industries either remained well below $10 \%$ (as in SSA and MENA) or declined over time (as in LAC) in direct contrasts with the increasing employment share of this sub-sector in these regions. While medium-technology industries account for the majority of manufactured output around the world, this is by far the least export-oriented sector especially in developing countries including ASIA. The export ratio of high-technology industries is also not impressive with that of LAC and ASIA closely following OECD countries. The HT industries in the OECD are the only sector where there is a clear co-movement between export-output ratio and employment share.

Low-technology industries across all regions face higher import penetration rates in comparison with MT and HT industries. Strikingly, LT industries in developing countries are experiencing increasingly higher rates of import penetration rate than their 
counterparts in OECD countries. Also, increasing is import penetration in MT industries in developing countries, exceeding that of OECD countries since 2000. Import penetration in LAC countries is larger than any other region across all industries.

\section{Econometric approach}

Given the industry-level panel data for a large sample of countries, the econometric model we estimate takes the following form:

$$
\begin{aligned}
& \ln (L)_{i j t}=\delta+\beta \ln (V)_{i j, t-1}+\alpha \ln (w)_{i j, t-1}+\phi\left(\frac{X}{Y}\right)_{i j, t-1}+\phi\left(\frac{M}{M+Y}\right)_{i j, t-1}+ \\
& \psi \ln (w)_{i j, t-1} * s_{i j, t-1}+i j+u_{t}+\varepsilon_{i j t}
\end{aligned}
$$

where $L$ is labor, $V$ is real value added, $w$ is real wage rate, $\frac{X}{Y}$ is export-output ratio, $\frac{M}{M+Y}$ is import penetration rate, $s$ is the labor share of output, and the subscripts $i$ and $j$ index, respectively, countries and four-digit industries while $t$ indexes year. The term $i j$ is a country-industry fixed effect, $u_{t}$ stands for time fixed effects, and $\varepsilon_{i j t}$ represents time varying equation errors. Equation (5) is estimated using panel data that uniquely identify a four-digit industry for each sample country. The garments industry in Bangladesh is thus uniquely identified from the garments industry in India.

The interaction term between the labor share of output and wage rate emanates from our discussion in Section 2, where Eq. (2) is expressed as $\eta_{L L}=-\sigma-S_{L}(\eta-\sigma)$. Here, the labor share of output, assuming it remains stable over time in a given industry, acts as a weight for the net effect of the elasticities of substitution of inputs and final goods on $\eta_{L L}$. Therefore, $\psi$ in Eq. (5) captures the differential own-price elasticity of labor demand for industries with higher share of labor. ${ }^{10}$ For instance, if $\psi$ is positive and significant, it implies that the wage elasticity of labor demand declines with the labor share of output and that $\sigma>\eta$. Identification of the own-price elasticity of labor demand is based on the assumption that labor supply is perfectly elastic at the four-digit SIC level. While this may seem to be a strong assumption, the level of disaggregation in our analysis at four digits is reasonably small such that it is not an egregious misrepresentation (Slaughter 2001). For developing countries with high unemployment rates and small share of manufacturing in total employment, this assumption is rather reasonable. If that is not the case, our model may overstate the wage elasticity of labor demand.

The decision to use the intensity of exports and imports to capture the employment effects of trade integration is partly data-driven. The majority of developing countries in our sample implemented major trade liberalizations during the second half of the 1980s and at the beginning of the 1990s. The fact that our data begins in 1990 or later for some countries excludes trade policy shifts as control variables. It is also a common practice to use trade flows in the growth and trade literature as they show real exposure to international trade. ${ }^{11}$

While we assume exogenous demand for manufactures from domestic and export markets, potential endogeneity of explanatory variables arise partly because of simultaneous determination of employment, output, exports, and intermediate imports. We address this problem to an extent by taking 1-year lags of all explanatory variables. We also use the panel fixed effects estimator to account for unobserved technical and market 
characteristics that are industry specific and time invariant. This estimator will also address the influence of country fixed effects. The time fixed effects will capture variations over time in interest rates and other macroeconomic shocks that are common to all industries. Since sample countries are at different stages of industrialization and success in one industry could have spillover effects on related industries, it is unrealistic to assume independence of $\varepsilon_{i j t}$ across industries within a country. Robust standard errors will thus be used throughout the analysis.

Despite these safeguards, the panel fixed effects model is unlikely to address all the endogeneity problems satisfactorily. Job losses in specific manufacturing industries may trigger selective trade protection measures that reduce imports, while increased female labor force participation and/or migration may fuel export competitiveness. Therefore, we use instrumental variables to account for problems of reverse causation and time varying un-observables and obtain exogenous variation in import penetration rate and export orientation as well as real wages and real value added.

The instruments we construct are country and industry specific and vary over time. One of our instruments for import penetration rate is a weighted average exchange rate index of major import supplier countries to a particular industry of a given country. Since the US Dollar is the currency of choice for most international transaction, we use US Dollar exchange rates of import partner countries. Exchange rate indices from the IMF Financial Statistics database are weighted by the source country's share in total imports of a country in a given industry using trade flows from the COMTRADE database. We also construct an average implicit GDP deflator of import supplier countries weighted in a similar fashion as an additional instrument for import penetration rate. The assumption is that exchange rates and price indices of key import supplier countries are exogenous to economic conditions in a specific industry of the importing country while affecting import costs.

The instruments for import penetration rate can be expressed as:

$$
\begin{aligned}
\operatorname{EXI}_{i j t} & =\sum_{k}\left(\frac{M_{i j k t}}{\sum_{k} M_{i j k t}}\right) \mathrm{EX}_{k t}^{\mathrm{US}} \\
\operatorname{PPI}_{i j t} & =\sum_{k}\left(\frac{M_{i j k t}}{\sum_{k} M_{i j k t}}\right) \operatorname{PPI}_{k t}
\end{aligned}
$$

where $\mathrm{EXI}_{i j t}$ is a weighted average exchange rate index of import supplier countries, $M_{i j k t}$ represents import by country $i$ from supplier country $k$ in industry $j$ at time $t$, and $\mathrm{EX}_{k t}^{\mathrm{US}}$ is US Dollar exchange rates of import supplier countries. $\mathrm{PPI}_{k t}$ represents implicit GDP deflators of source countries as a proxy for their producer price indices while $\operatorname{PPI}_{i j t}$ is a weighted average industry-specific index of import source countries.

In constructing the instruments for import penetration, we allow the composition of partner countries to vary across industries and over time, which together with the annual data on exchange rates and GDP deflators provide us with industry-specific instruments for each sample country. We use a $2.5 \%$ import share as a cutoff point to determine the set of import partner countries. The selected source countries account on average for $89 \%$ of industry-level imports in our sample. As much as data allow, we take three data points each 
for the 1990s and 2000s to allow changes in the composition of import source countries. In a few cases, data limitations restrict us to only two sets of partner countries, i.e., one set for the 1990s and another set for the 2000s.

Our instruments for import competition differ from that of Autor et al. (2013) where they used imports by other developed country from China to instrument US imports from China. Dauth et al. (2014) follow a similar approach for Germany. Unlike these authors, we examine the employment impact of import intensity in general rather than focusing on competition from emerging economies-China in the case of the US and China and East Europe in the case of Germany. Our approach measures the changes in import supplier countries directly rather than the indirect approach which relies on the behavior of importing countries at a similar level of development.

To instrument the export-output ratio, we construct industry-specific weighted average real exchange rate index for exporting countries. We use the official US dollar exchange rate index adjusted for industry-specific price indices. The producer price indices of major export destination countries are weighted by their respective export shares from a given industry using trade flows from COMTRADE. The official exchange rate is assumed to be exogenous to firms in a four-digit ISIC industry and so also are producer prices in the export destination countries. In addition to this, we also use a weighted GDP index of export destination countries to capture demand shocks in partner countries using the export shares as weights. To be included in the calculation of the real exchange rate index and the GDP index, a destination country should account for at least $2.5 \%$ of an industry's exports from a sample country. The selected destination countries account on average for $90 \%$ of industry-level exports from our sample.

The instruments for export-output ratio can be expressed as:

$$
\begin{aligned}
& \operatorname{REXI}_{i j t}^{\mathrm{US}}=\operatorname{EX}_{i t}^{\mathrm{US}}\left(\frac{\operatorname{PPI}_{i j t}}{\sum_{k^{\prime}}\left(\sum_{i j k^{\prime} t} X_{i j k^{\prime} t}\right) \operatorname{PPI}_{k^{\prime} t}}\right) \\
& \operatorname{GDPI}_{i j t}=\sum_{k^{\prime}}\left(\frac{X_{i j k^{\prime} t}}{\sum_{k^{\prime}} X_{i j k^{\prime} t}}\right) \operatorname{GDPI}_{k^{\prime} t}
\end{aligned}
$$

where REXI $\mathrm{US}$ is is weighted average real exchange rate index for export destination countries, $X_{i j k^{\prime} t} t$ is total export from industry $j$ of country $i$ to destination country $k^{\prime}$ at time $t, \mathrm{EX}_{i t}^{\mathrm{US}}$ is the official exchange rate of exporting country $i, \mathrm{PPI}_{i j t}$ is industry-level producer price index (from INDSTAT2) of exporting country, and $\mathrm{PPI}_{k^{\prime} t}$ is implicit GDP deflator of an export destination country. $\mathrm{GDPI}_{k^{\prime} t}$ is the GDP index of an export destination country while GDPI ${ }_{i j t}$ is the aggregate GDP index of export destination countries applicable to industry $j$ of an exporting country. ${ }^{12}$

Assuming that workers in a four-digit industry will consider the average wage in the respective two-digit industry as an alternative wage, we use the latter to instrument real wage rates at the four-digit level. The fact that we are using real wages already takes into account the two-digit producer price index in that industry. Real value added of each 
four-digit industry is instrumented by the real GDP of the same country to capture demand shocks from the entire domestic economy.

Following the discussion in Section 3, the labor demand model will be estimated separately for the six regions. By creating sub-samples of countries with comparable geographic, historical, and institutional backgrounds, we hope to further mitigate the effects of time varying country-level heterogeneity that our model does not control for. These include differences in technological capabilities, human capital, and institutional qualities that could affect the employment response to exogenous shocks in our covariates. The vast regional difference in industrial structure and dynamics shown earlier in Section 3 seem to support this strategy rather than imposing the same coefficient for all developed and developing countries.

Within each region, the employment model will also be estimated for the entire manufacturing sector as well as for high-, medium-, and low-technology industries. The idea is to allow for heterogeneous employment responses to exogenous shock in our covariates across groups of industries which may arise from unobserved technological and market characteristics. The observed structural differences in Section 3 support this classification of industries, which hopefully enhances the statistical precision and policy relevance of the econometric analysis.

\section{Estimation results ${ }^{13}$}

Table 4 presents estimates of the labor demand model for groups of developing, transition, and developed countries. As would be expected, we find a negative and statistically significant own-price elasticity of labor demand across all regions. In developing countries, the coefficient on real wage ranges from 0.44 in MENA to 0.54 in SSA with an average of 0.48 . Interestingly, Table 4 shows positive and statistically significant coefficients on the interaction term between real wages and the labor share of output for all regions. This suggests that the elasticity of employment with respect to real wages declines as the labor share of output increases. At average values of labor share, which is about $42 \%$ in developing countries, the results indicate about $5 \%$ reduction in the own-price elasticity of labor demand. This is consistent with the neoclassical factor demand theory where the rate of factor substitution declines as firms use more of one input keeping output constant. The sign of the interaction term also suggests that the elasticity of substitution of inputs for manufacturing firms is greater than consumers' elasticity of substitution between final products, although in theory the latter has no upper bound (Slaughter 2001). Formal comparison of coefficients in Appendix A: Table 10 in the Appendix shows that the coefficient on wage in OECD countries is significantly larger than coefficients in each developing region. Among developing countries, statistically significant differences exist mainly on the interaction term between labor share and log wages. ${ }^{14}$

Demand for manufactured goods has the expected positive and statistically significant effect on labor demand. Across the developing world, the average demand elasticity of employment is about 0.43 , i.e., a $1 \%$ growth in real value added leads to a $0.43 \%$ increase in employment. While coefficients on value added in Table 4 show statistically insignificant differences among developing regions, Appendix A: Table 10 shows that they are significantly lower than that of OECD countries. Given the actual contraction of manufacturing employment in the OECD, the positive demand elasticity indicates the 
Table 4 Estimated labor demand model by region: IV-panel fixed effects

\begin{tabular}{llllllll}
\hline & SSA & MENA & LAC & ASIA & DVPG & CEE & OECD \\
\hline Ln $(V)$ & $0.3597^{* * *}$ & $0.3724^{* * *}$ & $0.3935^{* * *}$ & $0.4614^{* * *}$ & $0.4337^{* * *}$ & $0.2770^{* * *}$ & $0.6402^{* * *}$ \\
& $(0.0336)$ & $(0.0206)$ & $(0.0227)$ & $(0.0149)$ & $(0.0096)$ & $(0.0109)$ & $(0.0082)$ \\
$M / M+Y)$ & $0.2437^{* * *}$ & $-0.3097^{* * *}$ & $-0.3961^{* * *}$ & 0.0214 & 0.0679 & $-0.3188^{* * *}$ & $-0.0600^{* *}$ \\
& $(0.0967)$ & $(0.0922)$ & $(0.0836)$ & $(0.0987)$ & $(0.0443)$ & $(0.0688)$ & $(0.0251)$ \\
$X Y$ & -0.0382 & -0.0045 & $0.0355^{* * *}$ & $0.0212^{* * *}$ & $0.0268^{* * *}$ & $0.0172^{*}$ & $0.0141^{* * *}$ \\
& $(0.0305)$ & $(0.0358)$ & $(0.0082)$ & $(0.0079)$ & $(0.0061)$ & $(0.0096)$ & $(0.0037)$ \\
Ln $(w)$ & $-0.5421^{* * *}$ & $-0.4406^{* * *}$ & $-0.4635^{* * *}$ & $-0.4785^{* * *}$ & $-0.4804^{* * *}$ & $-0.3649^{* * *}$ & $-0.6440^{* * *}$ \\
& $(0.0214)$ & $(0.0136)$ & $(0.0172)$ & $(0.0117)$ & $(0.0071)$ & $(0.0092)$ & $(0.0062)$ \\
Ln $(w)^{*} s$ & $0.0743^{* * *}$ & $0.0337^{* * *}$ & $0.1215^{* * *}$ & $0.0823^{* * *}$ & $0.0577^{* * *}$ & $0.0020^{* * *}$ & $0.0674^{* * *}$ \\
& $(0.0068)$ & $(0.0029)$ & $(0.0065)$ & $(0.0045)$ & $(0.0021)$ & $(0.0002)$ & $(0.0016)$ \\
Constant & $5.3675^{* * *}$ & $4.7048^{* * *}$ & $4.7174^{* * *}$ & $4.0743^{* * *}$ & $4.2927^{* * *}$ & $5.8563^{* * *}$ & $2.0429^{* * *}$ \\
& $(0.4848)$ & $(0.3097)$ & $(0.3828)$ & $(0.2517)$ & $(0.1581)$ & $(0.1741)$ & $(0.1382)$ \\
Observations & 1367 & 3619 & 2789 & 5235 & 13010 & 7950 & 16258 \\
Number of industries & 162 & 397 & 449 & 448 & 1456 & 1068 & 1501 \\
\hline
\end{tabular}

Note: All variables are lagged by one period. $V$ is real value added, $w$ is real wage, $s$ is the share of labor in output, $X / Y$ is the export share of output, and $M /(M+Y)$ is import penetration rate. Robust standard errors indicated in parentheses.*, $* *$, and ${ }^{* * *}$ represent statistical significance at 10,5 , and $1 \%$, respectively. DVPG refers to developing countries

reallocation of jobs from the declining LT industries toward better performing MT and HT industries.

The coefficients on real value added in Table 4 suggest that the employment benefits of industrialization in developing countries are rather moderate than what policymakers may have wished for. A developing country needs to maintain about $10 \%$ growth in real value added to achieve a $4.3 \%$ annual growth in manufacturing employment. However, performance indicators in Tables 1 and 2 suggest that such spectacular rates of valueadded growth are rather infrequent. In countries where population and labor force continue to grow at 2-3\% per annum, increasing the employment share of manufacturing may require even higher rates of industrial expansion.

While demand and wage elasticities of labor demand are remarkably similar across developing regions in terms of coefficient size and significance, Table 4 shows striking differences in the employment response to participation in international trade (see also Appendix A: Table 10). LAC and MENA are the only developing regions where import penetration significantly dampens domestic labor demand. This is not surprising in the case of LAC given its high import penetration rate relative to other developing regions. This finding is also consistent with existing country-level studies in Latin America as discussed earlier (Revenga 1997; Attanasio et al. 2004; Menezes-Filho and Muendler, 2011). Import penetration causes no adverse employment effects in ASIA, while it significantly increases employment growth in SSA. The latter is likely the result of better access to imported intermediate inputs more than offsetting the negative employment effects of competition from imported final products. While import competition has statistically significant job destruction effects in CEE and OECD countries, the employment effect in the OECD is rather marginal as compared to CEE.

Large regional differences also emerge in the employment effects of export orientation. Other things being equal, growth in manufactured exports increases labor demand significantly in LAC and ASIA. Positive albeit weaker employment effects of exports are also 
observed in CEE and OECD countries. Owing partly to their limited participation in export markets, employment in SSA and MENA does not vary with the export-output ratio of an industry. Overall, the evidence does not support the negative relationship between employment and export growth predicted by some of the new trade theories with heterogeneous firms. But our findings are more consistent with Felbermayr et al. (2011a) where export orientation increases job creation. Nonetheless, the coefficients on the export ratio are typically small even for regions where they are statistically significant and differences across regions are largely insignificant as shown in Appendix A: Table 10. Such unimpressive employment benefits suggest that the size and productivity advantages of exporting firms may have allowed them to increase exports with limited adjustment of labor.

The results in Table 4 reflect average employment responses across all manufacturing industries ignoring potential heterogeneity across groups of industries. By estimating the labor demand models for technology-based groups of industries, we allow employment responses to vary within each region. Table 5 examines employment in low-technology industries while Tables 6 and 7 report the results for medium- and high-technology industries, respectively. Because of limited number of observations for the SSA sample, Table 6 combines the MT and HT industries in Africa.

Table 5 indicates that for most countries, the elasticity of employment with respect to value added is larger in LT industries (by about ten percentage points) relative to the manufacturing sector averages reported in Table 4 (that of LAC and CEE are close to the average). This is not the case for MT industries in Table 6, where the coefficients on value added are typically lower than the respective regional average in Table 4 for all regions. These results are consistent with the descriptive statistics that LT industries are typically labor-intensive while MT industries tend to be capital-intensive. The employment intensity of value-added growth in HT industries (Table 7) is often better than MT industries but less than LT industries. LAC and CEE are exceptions where demand elasticities of employment in HT industries are stronger relative to LT industries. As discussed earlier, HT industries are the only industries in CEE and OECD countries that exhibited employment growth.

Table 5 Estimated labor demand model for low-technology industries by region: IV-panel fixed effects

\begin{tabular}{llllllll}
\hline & SSA & MENA & LAC & Asia & DVPG & CEE & OECD \\
\hline Ln $(V)$ & $0.4403^{* * *}$ & $0.5452^{* * *}$ & $0.3779^{* * *}$ & $0.6026^{* * *}$ & $0.5489^{* * *}$ & $0.2782^{* * *}$ & $0.7516^{* * *}$ \\
& $(0.0480)$ & $(0.0345)$ & $(0.0408)$ & $(0.0241)$ & $(0.0159)$ & $(0.0168)$ & $(0.0141)$ \\
$M /(M+Y)$ & -0.0290 & $-0.5260^{* * *}$ & -0.0830 & 0.1866 & -0.0586 & $-0.6591^{* * *}$ & $-0.2830^{* * *}$ \\
& $(0.1435)$ & $(0.1187)$ & $(0.1897)$ & $(0.1470)$ & $(0.0660)$ & $(0.1084)$ & $(0.0442)$ \\
$X Y$ & -0.0193 & $0.1211^{* * *}$ & -0.0163 & $0.0401^{* *}$ & $0.0346^{* *}$ & 0.0128 & $0.1343^{* * *}$ \\
& $(0.0299)$ & $(0.0425)$ & $(0.0452)$ & $(0.0157)$ & $(0.0135)$ & $(0.0176)$ & $(0.0096)$ \\
Ln $(w)$ & $-0.4931^{* * *}$ & $-0.5793^{* * *}$ & $-0.4370^{* * *}$ & $-0.6230^{* * *}$ & $-0.5629^{* * *}$ & $-0.3172^{* * *}$ & $-0.7399^{* * *}$ \\
& $(0.0342)$ & $(0.0275)$ & $(0.0288)$ & $(0.0215)$ & $(0.0134)$ & $(0.0157)$ & $(0.0111)$ \\
Ln $(w)^{*}$ S & $0.1110^{* * *}$ & $0.0775^{* * *}$ & $0.1401^{* * *}$ & $0.1784^{* * *}$ & $0.1284^{* * *}$ & $0.0013^{* * *}$ & $0.0507^{* * *}$ \\
& $(0.0138)$ & $(0.0100)$ & $(0.0124)$ & $(0.0090)$ & $(0.0054)$ & $(0.0002)$ & $(0.0021)$ \\
Constant & $3.8088^{* * *}$ & $2.9508^{* * *}$ & $4.8977^{* * *}$ & $2.3120^{* * *}$ & $2.7883^{* * *}$ & $5.6677^{* * *}$ & $0.9704^{* * *}$ \\
& $(0.6850)$ & $(0.4734)$ & $(0.7177)$ & $(0.3922)$ & $(0.2464)$ & $(0.2737)$ & $(0.2545)$ \\
Observations & 671 & 1143 & 944 & 1610 & 4368 & 2683 & 4692 \\
Number of industries & 80 & 127 & 145 & 139 & 491 & 347 & 435 \\
\hline
\end{tabular}

Note: See notes under Table 4 
Table 6 Estimated labor demand model for medium-technology industries by region: IV-panel fixed effects

\begin{tabular}{llllllll}
\hline & SSA & MENA & LAC & Asia & DVPG & CEE & OECD \\
\hline Ln $(V)$ & $0.3261^{* * *}$ & $0.3141^{* * *}$ & $0.3973^{* * *}$ & $0.2838^{* * *}$ & $0.3607^{* * *}$ & $0.4240^{* * *}$ & $0.5806^{* * *}$ \\
& $(0.0511)$ & $(0.0365)$ & $(0.0444)$ & $(0.0292)$ & $(0.0176)$ & $(0.0215)$ & $(0.0166)$ \\
$M /(M+Y)$ & $0.3232^{* *}$ & $-0.5156^{* *}$ & $-0.5473^{* * *}$ & $-0.4580^{* *}$ & $0.1886^{* *}$ & $-0.2788^{* *}$ & $-0.2495^{* * *}$ \\
& $(0.1323)$ & $(0.2418)$ & $(0.1523)$ & $(0.1977)$ & $(0.0757)$ & $(0.1288)$ & $(0.0626)$ \\
$X Y$ & -0.0092 & -0.0226 & 0.0353 & $0.0351^{* * *}$ & $0.0233^{* *}$ & 0.0144 & $0.0761^{* * *}$ \\
& $(0.1455)$ & $(0.0766)$ & $(0.0773)$ & $(0.0113)$ & $(0.0117)$ & $(0.0109)$ & $(0.0232)$ \\
$\operatorname{Ln}(w)$ & $-0.5740^{* * *}$ & $-0.3979^{* * *}$ & $-0.4930^{* * *}$ & $-0.3936^{* * *}$ & $-0.4630^{* * *}$ & $-0.4886^{* * *}$ & $-0.5816^{* * *}$ \\
& $(0.0302)$ & $(0.0214)$ & $(0.0311)$ & $(0.0213)$ & $(0.0117)$ & $(0.0180)$ & $(0.0119)$ \\
$\operatorname{Ln}(w)^{*} s$ & $0.0646^{* * *}$ & $0.0345^{* * *}$ & $0.1546^{* * *}$ & $0.0732^{* * *}$ & $0.0548^{* * *}$ & $0.0519^{* * *}$ & $0.0809^{* * *}$ \\
& $(0.0081)$ & $(0.0051)$ & $(0.0130)$ & $(0.0092)$ & $(0.0035)$ & $(0.0031)$ & $(0.0034)$ \\
Constant & $5.9938^{* * *}$ & $5.4613^{* * *}$ & $4.9503^{* * *}$ & $6.9532^{* * *}$ & $5.4960^{* * *}$ & $4.3036^{* * *}$ & $2.5997^{* * *}$ \\
& $(0.7348)$ & $(0.5998)$ & $(0.7560)$ & $(0.5174)$ & $(0.3044)$ & $(0.3289)$ & $(0.2906)$ \\
Observations & 696 & 1380 & 893 & 1600 & 4437 & 2539 & 5366 \\
Number of industries & 82 & 149 & 143 & 137 & 491 & 346 & 497
\end{tabular}

Note: See notes under Table 4

Although import penetration rates in LT industries are higher than other industries, this does not seem to induce significant reduction in labor demand in developing countries (Table 5). The only exception is the resource rich MENA region where the coefficient on import penetration is large, negative, and statistically significant. As developing countries have become the main sources of LT exports (accounting for about two thirds of total LT exports for countries in our sample), the absence of a strong adverse employment effect of imports in this sector could be the result of trade among developing countries. For developed and transition economies, however, LT imports cause significant displacement of low-skill jobs. This indicates the relative competitiveness of developing countries in LT

Table 7 Estimated labor demand model for high-technology industries by region: IV-panel fixed effects

\begin{tabular}{lllllll}
\hline & MENA & LAC & ASIA & DVPG & CEE & OECD \\
\hline $\operatorname{Ln}(V)$ & $0.3715^{* * *}$ & $0.4394^{* * *}$ & $0.3771^{* * *}$ & $0.4335^{* * *}$ & $0.4098^{* * *}$ & $0.6365^{* * *}$ \\
& $(0.0506)$ & $(0.0361)$ & $(0.0315)$ & $(0.0209)$ & $(0.0243)$ & $(0.0144)$ \\
$M /(M+Y)$ & -0.1984 & $-0.4408^{* *}$ & 0.1953 & -0.0517 & -0.1176 & $0.1222^{* *}$ \\
& $(0.1926)$ & $(0.1821)$ & $(0.1734)$ & $(0.1059)$ & $(0.1241)$ & $(0.0505)$ \\
$X Y$ & -0.1101 & $0.0480^{* * *}$ & -0.0059 & $0.0294^{* * *}$ & 0.0160 & -0.0020 \\
& $(0.0974)$ & $(0.0078)$ & $(0.0148)$ & $(0.0089)$ & $(0.0318)$ & $(0.0043)$ \\
$\operatorname{Ln}(W)$ & $-0.5269^{* * *}$ & $-0.5007^{* * *}$ & $-0.4396^{* * *}$ & $-0.5072^{* * *}$ & $-0.5031^{* * *}$ & $-0.6869^{* * *}$ \\
& $(0.0302)$ & $(0.0323)$ & $(0.0195)$ & $(0.0138)$ & $(0.0182)$ & $(0.0111)$ \\
$\operatorname{Ln}(w)^{*}$ S & $0.0953^{* * *}$ & $0.0831^{* * *}$ & $0.0457^{* * *}$ & $0.0717^{* * *}$ & $0.0232^{* * *}$ & $0.0953^{* * *}$ \\
& $(0.0110)$ & $(0.0095)$ & $(0.0069)$ & $(0.0049)$ & $(0.0017)$ & $(0.0036)$ \\
Constant & $5.0214^{* * *}$ & $4.1416^{* * *}$ & $5.4001^{* * *}$ & $4.4400^{* * *}$ & $4.4876^{* * *}$ & $2.3626^{* * *}$ \\
& $(0.7198)$ & $(0.5628)$ & $(0.5494)$ & $(0.3390)$ & $(0.3540)$ & $(0.2277)$ \\
Observations & 983 & 870 & 1821 & 3797 & 2449 & 5527 \\
Number of industries & 107 & 144 & 155 & 424 & 337 & 506 \\
\hline
\end{tabular}

Note: See notes under Table 4 
industries and our findings support the view that trade with developing countries reduce jobs in high-income countries (Autor et al. 2013).

As shown in Table 6, jobs in medium-technology industries are particularly susceptible to import competition across all regions except SSA. Unlike the LT industries, the employment-reducing effects of import competition in MT industries are a bit stronger for developing countries as compared to CEE and OECD countries. Until very recently, more than $50 \%$ of world exports of MT products are supplied by OECD countries showing their competitive advantage. MT industries in Africa seem to benefits from increased import penetration, which could be explained by better access to intermediate inputs. Jobs in high-technology industries are by far the least sensitive to import competition relative to LT and MT industries. The only exception is Latin America where statistically significant employment contraction occurs as a result of import penetration. On the flip side, the two regions that dominate world exports in HT industries, i.e., OECD and ASIA, have positive employment elasticities with respect to import penetration, although the coefficient for ASIA is not statistically significant. This suggests that greater trade openness in high-technology industries could be beneficial for most countries.

Not all developing countries benefit from export-oriented low-technology manufacturing. Table 5 shows that only MENA and ASIA have statistically significant employment benefits from LT exports. Interestingly, the coefficient on export-output ratio is positive and significant for LT industries of the OECD suggesting that export orientation helps slowdown the rate of job destruction in this sector. This is consistent with the declining employment share and increasing export ratio of this sector in the OECD (Fig. 2). Export orientation in MT industries has employment benefits only in ASIA and OECD regions suggesting these are the dominant exporters in this industry.

High-technology exports are not important sources of employment gain with the exception of LAC where the coefficient is positive and significant. The size of the coefficient on export ratio is quite low even when statistically significant reaffirming the limited contribution of export-oriented manufacturing for job creation. Once again, the fact that exporters are relatively large and productive seems to allow them to increase exports with limited job creation. Equally important is the observation that export orientation is not endangering existing jobs as some of the latest trade theories predicted.

Summing up, low-technology industries still seem to have significant employment potentials for developing countries. A shift toward MT manufacturing may increase productivity and value-added growth in developing countries, as shown earlier in Fig. 2, but such a transition is less likely to generate more employment because of the capitalintensive nature of the sector and its limited export orientation. From an employment perspective, a structural change that favors HT over MT industries may serve developing countries better as their human capital and per capita income continue to rise. This is partly because the output share of HT industries in total manufacturing is still very low in developing countries and employment in this sector is far less susceptible to import competition. The latter is perhaps an indication of the role of intermediate inputs as well as growing FDI flows in this sector from OECD to developing countries.

\section{Extended model}

In this section, we extend the labor demand model by considering additional dimensions of export activities. Countries and industries with comparable export-output ratios may 
differ in the range of export items, i.e., the extensive margin. Hausmann et al. (2007) argue that the discovery of new export items is bound to be sub-optimal because of sunk costs that are private and the public-good nature of successful new export products. The authors also show diversification as an important predictor of both the level and future growth rate of per capita income. In a related literature, Bernard et al. (2010) and Goldberg et al. (2010) find that multiproduct firms are significantly larger, more productive, and more export oriented than single product firms. Whether diversification affects employment opportunities, holding export-ratio constant, is thus worth exploring.

Our conjecture is that the employment benefits of adding a new export item may depend on the current diversity of the export basket. For a developed country with a broad range of manufactured export items, adding one more product may not have a noticeable employment effect as compared to a developing country with only a few export items. We attempt to explore this relationship by including in the labor demand model the total number of six-digit export items (HS codes) within a four-digit ISIC industry and compare the outcome for developed and developing countries.

Once a new export item is introduced, subsequent employment growth will be driven by the intensive margin, which in turn depends partly on the competitiveness of the global market in that particular industry. Products with relatively low discovery costs are likely to be exported by firms from multiple countries. With fewer buyers and many suppliers, importers may exercise market power and use the threat of switching supplier countries/ firms to dictate the terms of exchange in their advantage. The resulting uncertainty of demand and contract terms may reduce exporters' incentive and ability to create and retain jobs. To capture this effect, the extended labor demand model includes a measure of the number of active exporter countries (CX) for each four-digit industry.

Finally, constraints to job creation may arise from inadequate investments in machinery and equipment. Since Eq. (5) already controls for value added, the focus here is on the role of investment on labor productivity of domestic firms facing competitive pressure. One example is the reduction in maintenance cost and down time by replacing old machines by new ones. The productivity effect could also be associated with the increase in the scale of production as investment intensifies. We expect such complementary employment effects to be important for countries at early stages of industrialization. For others, high investment rates may dampen labor demand as production becomes more capital-intensive. The extended model includes the investment rate as one of the explanatory variables, and it is calculated as the percentage of manufactured output dedicated for investment purposes. The extended model is expressed as follows:

$$
\begin{aligned}
& \ln (L)_{i j t}=\delta+\beta \ln (V)_{i j, t-1}+\alpha \ln (w)_{i j, t-1}+\phi\left(\frac{X}{Y}\right)_{i j, t-1}+\phi\left(\frac{M}{M+Y}\right)_{i j, t-1}+ \\
& \psi \ln (w)_{i j, t-1} * s_{i j, t-1}+\gamma \ln (\mathrm{HS})_{i j, t-1}+\pi \ln (\mathrm{CX})_{i j, t-1}+i j+u_{t}+\varepsilon_{i j t}
\end{aligned}
$$

The results from the extended model are presented in Table 8. Because of the substantial reduction in the number of observations due to missing values for the new variables, the extended model is first estimated for the entire manufacturing sector without delving into technology-based industry categories. The coefficients on previously discussed covariates remain similar to those in Table 4 with minor differences in magnitude and a few 
losses of precision due to sample size reduction. Therefore, the remaining discussion focuses on the new variables in the extended model.

A key observation is the positive and statistically significant coefficient on the number of export items (HS) for developing countries. This is particularly true in SSA and LAC countries and to a certain extent in MENA too. This suggests that after controlling for export-output ratio, adding new export items has significant employment benefits for countries that have yet to become accomplished exporters of manufactures. No such employment benefits accompany export diversification in ASIA and OECD countries, which currently dominate world exports of manufactures. The marginal employment benefits from product adding seem to decline with the scale of export activities. This appears to resonate with the findings of Imbs and Wacziarg (2003) that as countries develop, their economies become increasingly less (more) concentrated (diversified) until a threshold level of per capita income is reached, beyond which specialization kicks in.

Participating in export markets in which there are a large number of competitors does not have any noticeable employment effects. Nonetheless, there is some evidence that exporting what most other countries export increases job opportunities in SSA. This suggests that countries with limited technological capabilities can get a foothold in international markets by exporting items with low discovery costs. Similarly, the fact that the coefficient on CX is negative for the Asian sample, despite lacking precision, suggests that the region is approaching a point where industrial expansion and job creation through low-technology exports may no longer be a viable option. This opportunity is about to

Table 8 Extended labor demand model by region: IV-panel fixed effects

\begin{tabular}{|c|c|c|c|c|c|c|c|}
\hline & SSA & MENA & LAC & ASIA & DVPG & CEE & OECD \\
\hline \multirow[t]{2}{*}{$\operatorname{Ln}(V)$} & $0.3352^{* * *}$ & $0.3631^{* * *}$ & $0.2503^{* * *}$ & $0.4066^{* * *}$ & $0.3084^{* * *}$ & $0.3115^{* * *}$ & $0.6764^{* * *}$ \\
\hline & $(0.0502)$ & $(0.0350)$ & $(0.0335)$ & $(0.0286)$ & $(0.0158)$ & $(0.0220)$ & $(0.0139)$ \\
\hline \multirow[t]{2}{*}{$M /(M+\gamma)$} & 0.0784 & $-0.6395^{* * *}$ & $-0.6473^{* * *}$ & $-0.2628^{* *}$ & $-0.3702^{* * *}$ & $-0.4983^{* * *}$ & 0.0200 \\
\hline & $(0.1441)$ & $(0.1099)$ & $(0.1161)$ & $(0.1159)$ & (0.0599) & $(0.0836)$ & $(0.0494)$ \\
\hline \multirow[t]{2}{*}{$X Y$} & 0.0002 & 0.0338 & $0.0430^{* * *}$ & -0.0012 & $0.0188^{* * *}$ & 0.0068 & $0.0126^{* * *}$ \\
\hline & $(0.0308)$ & $(0.0335)$ & $(0.0088)$ & $(0.0084)$ & $(0.0060)$ & $(0.0102)$ & $(0.0033)$ \\
\hline \multirow[t]{2}{*}{$\operatorname{Ln}(w)$} & $-0.4880^{* * *}$ & $-0.4128^{* * *}$ & $-0.3239^{* * *}$ & $-0.4079^{* * *}$ & $-0.3674^{* * *}$ & $-0.2919^{* * *}$ & $-0.6771^{* * *}$ \\
\hline & $(0.0344)$ & $(0.0240)$ & $(0.0253)$ & $(0.0245)$ & $(0.0124)$ & $(0.0194)$ & $(0.0122)$ \\
\hline \multirow[t]{2}{*}{$\operatorname{Ln}(w)^{*} S$} & $0.0731^{* * *}$ & $0.0209^{* * *}$ & $0.0747^{* * *}$ & $0.1174^{* * *}$ & $0.0378^{* * *}$ & $0.0203^{* * *}$ & $0.0989^{* * *}$ \\
\hline & $(0.0107)$ & $(0.0033)$ & $(0.0087)$ & $(0.0102)$ & $(0.0027)$ & $(0.0017)$ & $(0.0032)$ \\
\hline \multirow[t]{2}{*}{ Ln (HS) } & $1.0269^{* * *}$ & $0.1124^{b}$ & $2.2233^{* * *}$ & 0.2012 & $0.2922^{* * *}$ & $0.7878^{* * *}$ & $0.1813^{d}$ \\
\hline & $(0.2831)$ & $(0.0762)$ & $(0.4782)$ & $(0.3500)$ & $(0.0565)$ & $(0.1338)$ & (0.1194) \\
\hline \multirow[t]{2}{*}{$\operatorname{Ln}(C X)$} & $0.4071^{\mathrm{a}}$ & 0.0289 & 0.1368 & -0.1497 & 0.0705 & 0.1752 & 0.0307 \\
\hline & $(0.2527)$ & $(0.1928)$ & $(0.1635)$ & $(0.1641)$ & $(0.0964)$ & $(0.1902)$ & $(0.0542)$ \\
\hline \multirow[t]{2}{*}{ I/Y } & $0.4089^{* *}$ & $0.0925^{* *}$ & -0.0805 & 0.0234 & $0.0315^{c}$ & -0.0067 & $0.0810^{b}$ \\
\hline & $(0.1927)$ & $(0.0418)$ & $(0.0641)$ & $(0.0246)$ & $(0.0201)$ & $(0.0189)$ & $(0.0547)$ \\
\hline \multirow[t]{2}{*}{ Constant } & -2.9992 & $4.1023^{* * *}$ & $-10.0472^{* * *}$ & $4.0980^{*}$ & $3.5978^{* * *}$ & -1.3813 & 0.1106 \\
\hline & (2.1329) & $(1.1365)$ & (3.3685) & $(2.3353)$ & $(0.6381)$ & $(1.3317)$ & $(0.9039)$ \\
\hline Observations & 534 & 1104 & 1322 & 1551 & 4511 & 2211 & 6357 \\
\hline Number of industries & 57 & 131 & 201 & 148 & 537 & 352 & 716 \\
\hline
\end{tabular}

Note: See notes under Table 4. HS is the number of six-digit export items in a 4-digit industry, $C X$ is the number of competing countries, and $I / Y$ is the investment rate. Superscripts $a, b, c$, and $d$ represent statistical significance at 11,13 , 14 , and $12 \%$, respectively 
avail itself to low-cost countries in Africa. The other interesting result in Table 8 is the positive and significant relationship between investment and employment in developing countries as a group with the exception of LAC. It is striking that the employment effects of investment are larger and highly significant for manufacturing industries in SSA.

In Table 9, we allow the coefficients of the new variables to vary across technologybased industry categories. Medium- and high-technology industries for developing countries are merged together to economize on observations. The results show that labor demand in developing countries increases significantly as new export items (HS) are added to both LT and the combined MT/HT industries. However, the employment benefits are substantially larger in the MT/HT industries reflecting perhaps greater possibilities for diversification in more advanced industries. This is consistent with Hausmann et al. (2007) where growth in per capita income increases with the introduction of new products in technologically advanced industries. Product adding also helps developed countries create manufacturing jobs but only in the HT industries; even then, the coefficient on HS is barely significant. The coefficient on CX that proxies the competitiveness of export markets at the industry level is negative for the most part as would be expected but statistically insignificant. For LT industries in developing countries, however, an increase in the number of competing countries seems to increase employment.

While investment increases job creation in developing countries as shown in Table 8, only in LT industries does this complementarity turn out to be statistically significant. This seems to be consistent with the observed increase in the employment share of LT

Table 9 Extended labor demand model by region and industry group: IV-panel fixed effects

\begin{tabular}{|c|c|c|c|c|c|}
\hline & \multicolumn{2}{|c|}{ Developing countries } & \multicolumn{3}{|c|}{ OECD countries } \\
\hline & Low-tech & Med/high-tech & Low-tech & Med-tech & High-tech \\
\hline \multirow[t]{2}{*}{$\operatorname{Ln}(V)$} & $0.4288^{* * *}$ & $0.2261^{* * *}$ & $0.7620^{* * *}$ & $0.6067^{* * *}$ & $0.5924^{* * *}$ \\
\hline & $(0.0214)$ & $(0.0247)$ & $(0.0208)$ & $(0.0237)$ & $(0.0426)$ \\
\hline \multirow[t]{2}{*}{$M /(M+Y)$} & $-0.2558^{* * *}$ & $-0.4861^{* * *}$ & $-0.3644^{* * *}$ & $-0.4502^{* * *}$ & $0.2714^{* * *}$ \\
\hline & $(0.0811)$ & $(0.0859)$ & $(0.0877)$ & $(0.1002)$ & $(0.0898)$ \\
\hline \multirow[t]{2}{*}{$X Y$} & $0.0347^{* * *}$ & $0.0172^{* *}$ & $0.1199^{* * *}$ & $0.1186^{* * *}$ & -0.0025 \\
\hline & $(0.0132)$ & $(0.0069)$ & $(0.0102)$ & $(0.0225)$ & $(0.0044)$ \\
\hline \multirow[t]{2}{*}{$\operatorname{Ln}(w)$} & $-0.4815^{* * *}$ & $-0.3286^{* * *}$ & $-0.7149^{* * *}$ & $-0.6477^{* * *}$ & $-0.6969^{* * *}$ \\
\hline & $(0.0181)$ & (0.0178) & $(0.0200)$ & $(0.0214)$ & $(0.0322)$ \\
\hline \multirow[t]{2}{*}{$\operatorname{Ln}(w)^{*} S$} & $0.1161^{* * *}$ & $0.0231^{* * *}$ & $0.1374^{* * *}$ & $0.0945^{* * *}$ & $0.0772^{* * *}$ \\
\hline & $(0.0066)$ & $(0.0031)$ & $(0.0061)$ & $(0.0053)$ & $(0.0074)$ \\
\hline \multirow[t]{2}{*}{$\operatorname{Ln}(H S)$} & $0.1911^{* * *}$ & $0.3515^{* * *}$ & 0.0403 & -0.1885 & $0.6140^{\mathrm{a}}$ \\
\hline & $(0.0720)$ & $(0.0864)$ & $(0.1689)$ & $(0.1675)$ & $(0.3980)$ \\
\hline \multirow[t]{2}{*}{$\operatorname{Ln}(C X)$} & $0.2196^{*}$ & -0.1575 & -0.0085 & 0.0970 & -0.1306 \\
\hline & $(0.1235)$ & $(0.1465)$ & $(0.1118)$ & $(0.0679)$ & $(0.1206)$ \\
\hline \multirow[t]{2}{*}{ I/Y } & $0.0433^{*}$ & 0.0297 & -0.0684 & -0.1055 & $0.2332^{* *}$ \\
\hline & $(0.0249)$ & $(0.0317)$ & (0.1273) & $(0.0831)$ & (0.0995) \\
\hline \multirow[t]{2}{*}{ Constant } & $2.1329^{* * *}$ & $5.4557^{* * *}$ & -0.1446 & $3.7549^{* * *}$ & -0.5908 \\
\hline & $(0.8238)$ & $(0.9565)$ & $(1.3057)$ & $(1.2790)$ & $(3.0254)$ \\
\hline Observations & 2430 & 2081 & 2811 & 2234 & 994 \\
\hline Number of industries & 287 & 250 & 314 & 254 & 114 \\
\hline
\end{tabular}

Note: See notes under Table 4. HS is the number of six-digit export items in a four-digit industry, CX is the number of competing countries, and $I / Y$ is the investment rate. Superscripts a represents statistical significant at $13 \%$ 
industries in the developing world except for ASIA (Fig. 1a). On the other hand, investment in OECD manufacturing complements job creation only in HT industries while it tends to be negatively related with employment in both LT and MT industries. Capital flows from OECD countries to LT industries of developing countries could thus lead to a win-win situation.

\section{Conclusions}

This paper provides industry-level analysis of manufacturing employment using panel data from a large sample of developing, transition, and developed countries. The labor demand model is inspired by the literature in labor economics as well as recent developments in trade theory with heterogeneous firms. We allow the elasticities of labor demand to vary across regions as well as groups of industries at different levels of technological advancement. By using the same data sources, estimation model/method, and level of disaggregation for a large sample of countries, the paper provides a better understanding of the state of manufacturing employment in an increasingly integrated global economy.

While industrial expansion generates employment opportunities in developing countries, we find the elasticity of employment with respect to value-added growth to be far less than proportional suggesting that developing countries may need to sustain atypically higher rates of real value-added growth (above $10 \%$ ) to increase manufacturing employment by about $4 \%$ on average. In fact, the cross-country comparison of employment growth suggests that job creation in manufacturing tends to slowdown with the maturity and technological advancement of the sector. For developed countries, for instance, value-added growth and exports at best reduce the rate of job destruction in manufacturing.

While the own-price elasticity of labor demand is negative across all regions, the degree of responsiveness declines as the labor share of output increases which is consistent with the neoclassical factor demand model. The employment effect will thus be larger for developing regions experiencing relatively faster growth rates in real wages such as ASIA countries.

In low-technology industries where developing countries have comparative advantage, the adverse employment effects of import competition are rather insignificant-the resource rich MENA region being an outlier. For developed and transition economies, however, import penetration in LT industries reduces domestic labor demand significantly. Developing countries experience substantial employment contractions due to import competition in the more capital-intensive medium-technology industries. The only exception to the latter is SSA where import penetration and employment are positively related. Jobs in the emerging high-technology industries in developing countries, excluding LAC, are not susceptible to import penetration presumably because of the associated flows of technologies and intermediate inputs. HT industries in OECD countries gain employment as imports intensify testifying to the region's competitive advantage in this sector.

The export intensity of manufacturing does not seem to have substantial employment benefits for developing countries. Cases where export orientation contributes to employment growth include LT and MT industries in ASIA and HT industries in LAC. However, we do not find any employment reducing effects of exports as implied by some of the recent trade theories with imperfect labor markets. In fact, for OECD countries, exports 
seem to slowdown the rate of job destruction in LT industries. On the other hand, diversifying the export basket by adding new products contributes significantly to employment growth in developing countries particularly in the MT and HT industries. Product adding also helps create jobs in OECD countries but only in the HT industries.

The paper also underscores the importance of allowing for regional differences in understanding the dynamics of manufacturing employment. A few generalizations can be made in this regard. Latin American and Caribbean countries have the highest import penetration rate in the developing world and suffer most from import-induced job losses in their MT and HT industries with only marginal employment gains from HT exports. To make matters worse, value-added growth in the labor-intensive LT industries has started to slowdown in LAC since the year 2000. On the bright side, employment in this region is strongly responsive to diversification of export items.

Although manufacturing employment in Sub-Saharan Africa does not seem to suffer from growing imports and may even benefit from it, few of its industries are export oriented. Domestic demand for manufactures will likely set the growth path of manufacturing in this region and its employment contributions in the foreseeable future. Luckily, African manufacturing is responding favorably to the addition of new export items and to investment in machinery and equipment. Obviously, more FDI can address simultaneously the investment and export diversification efforts in this region.

Among developing regions, Asian countries have by far the most promising outlook in terms of manufacturing employment. Although declining over time, LT industries still account for about a third of manufacturing employment in this region while MT and HT industries are rising to fill this gap. Export orientation in the LT and MT industries also contribute to manufacturing employment as already indicated. A challenge for the region is strengthening the competitiveness of MT industries where imports tend to curb domestic labor demand. Given rising real wages in the region, improving labor productivity is imperative to sustain competitiveness.

Middle East and North African countries are doing better than SSA with growing participation in the export of manufactures. The dominance of capital-intensive medium-technology industries may suppress employment growth in MENA together with susceptibility to import competition. On the other hand, MENA has the highest investment rate in manufacturing than any other region, and this seems to have significant contributions to job creation.

\section{Endnotes}

${ }^{1}$ While Fallon and Lucas (1993) find that job security laws in India and Zimbabwe reduce labor demand, this claim has been disputed by subsequent studies on Indian labor markets (Bhalotra 1998).

${ }^{2}$ Felbermayr et al. (2011a) mention that their model does not address the labor market implications of trade between structurally different countries.

${ }^{3}$ Davidson et al. (2008) propose another trade model with search frictions. While they do not examine unemployment per se, they model firm level productivity as endogenous (rather than a random draw as in most Melitz-type models) to firms' 
choice of technology. They argue that firms that choose advanced technology hire highly skilled workers (because of the complementarity) and become more productive. Such firms engage in export activities once trade is opened up. Lowtechnology firms hire relatively less skilled workers and achieve productivity levels that allow them to serve only the domestic market. Wage differences across firms reflect underlying choices of technology and skill composition of workers, and this inequality increases after the removal of trade restrictions. Underemployment can happen in the Davidson et al. (2008) model if high-skilled workers are matched with low-technology firms.

${ }^{4}$ Based on four-digit ISIC industries from UK manufacturing during the 1980s, Greenaway et al. (1999) find that both imports and exports reduce domestic employment significantly. Revenga (1992) also finds a negative employment effect of reduction in import prices for US manufacturing industries during 1977-1987 while Sachs et al. (1994) substantial employment reduction especially in low-wage sectors. Examining Mexico's trade liberalization in the late 1980, Revenga (1997) shows a downward shift in labor demand.

${ }^{5}$ A firm level study by Pavcnik (2002) for Chilean manufacturing and industry-specific studies by Schor (2004) and Iscan (1998) for Brazil and Mexico, respectively, find significant productivity improvements in the manufacturing industries after trade liberalization but did not analyze labor market outcomes. Also, see Kim (2000) for productivity enhancing effects of trade in South Korean industries.

${ }^{6}$ The 2009 data is excluded from the summery statistics to avoid the effects of a sharp drop in manufacturing performance at the beginning of the recent global financial crisis.

${ }^{7}$ Kapsos (2005) makes similar observation using employment data for entire economies including manufacturing.

${ }^{8}$ The OECD classification identifies four categories: low, medium-low, medium-high, and high technology industries. While the printing and paper industry is classified as lowtechnology by the OECD with the highest score within this group, in our paper, we classify it as medium technology. We also lump together the medium-low and medium-high categories into one medium-technology category except that we reclassified the scientific instruments, motor vehicles, and electronic machinery in the high technology category instead of putting them in the medium-high group. These three industries ranked at the top of the medium-high technology based on R\&D intensity (see Table 3 of Hatzichronoglou 1997). This change in cutoff points is made to allow sufficient number of observation in applying the OECD classification to less industrialized countries.

${ }^{9}$ Employment in high-technology industries also grew faster in SSA and MENA although this is a rather narrow experience restricted to the transport equipment industry, which emerged only recently.

${ }^{10}$ The average labor share of output in our sample does not have a clear trend over time suggesting that $s$ in Eq. (5) is a shift variable for industry level differences within a country. This was discovered by running cross-sectional and panel fixed effects regressions of labor share on a time variable which show statistically insignificant coefficients with or without controls for trade. The only exception is SSA where there has been three percentage points reduction in labor share and OECD countries with a fifth of a percentage point increase in labor share.

${ }^{11}$ The time span of our data also has an advantage in the sense that the countries in our sample have relatively less divergent trade policy stances than would have been the 
case before 1990. This allows us to focus on the labor market effects of actual exposure to trade and underlying differences in economic structure.

${ }^{12}$ For developing countries where export earnings are driven by primary commodity exports, the nominal exchange rate itself is expected to be exogenous for four-digit manufacturing industries.

${ }^{13}$ First stage estimation results are provided in Appendix B. The F-test shows that our results are not suffering from weak instruments except for the export-out ratio in some regions.

${ }^{14}$ See Appendix A: Tables 11, 12, 13 for similar comparisons for technology based industrial groups.

\section{Appendix}

\section{Appendix A: Comparison of coefficients}

Table 10 Regional comparison of labor demand models

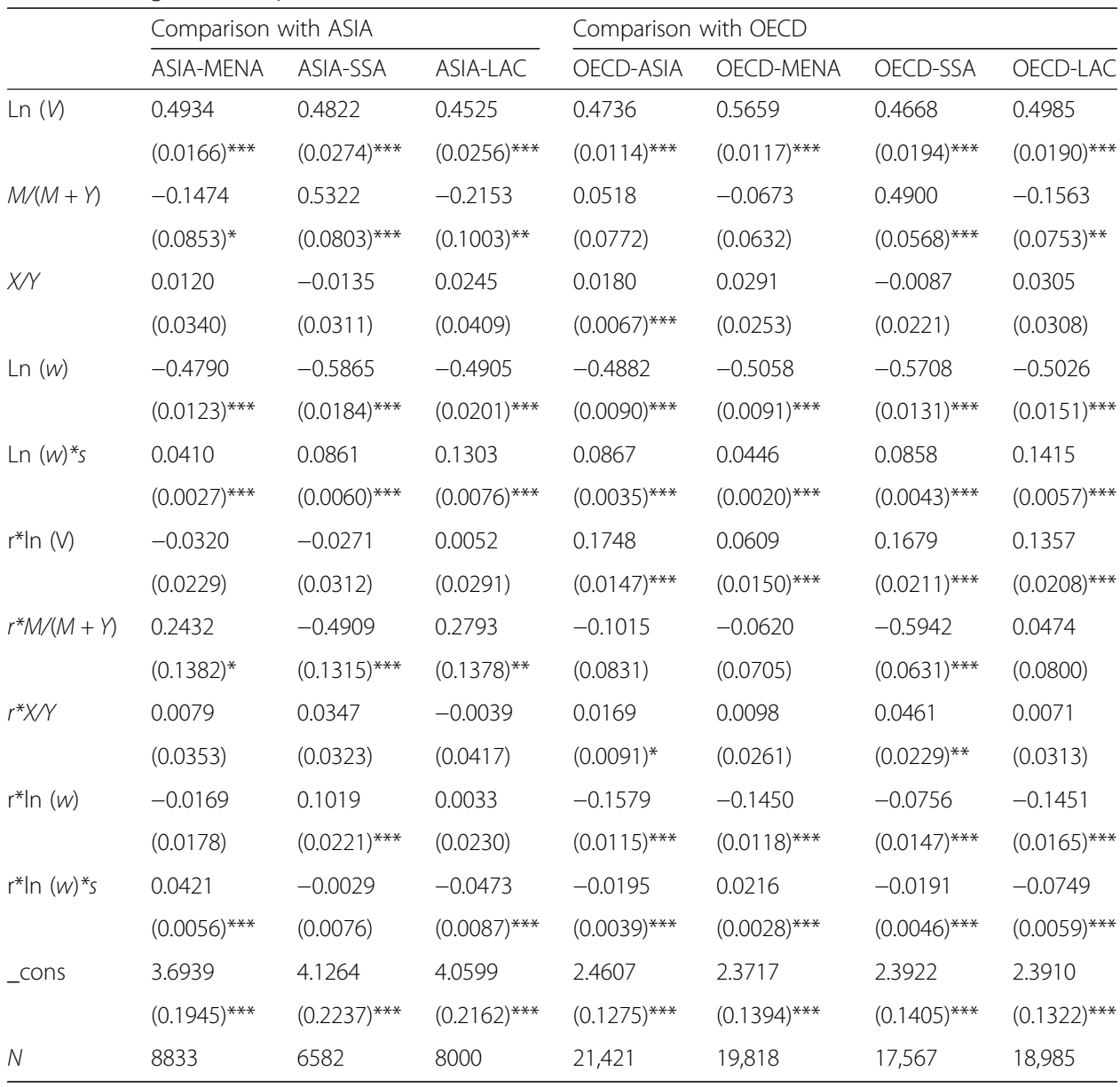

Note: See notes under Table 4

Note: The interaction terms $R^{*}[]$ are interaction between a region dummy variable $R$ and the other regressors In columns $1-3$, the dummy variable $R$ takes the value 1 for ASIA and 0 for the other region mentioned in the column head. For instance in column $1, R$ takes the value 1 for ASIA and 0 for MENA. In columns 4-7, $R$ takes the value 1 for OECD and 0 for other regions indicated in the column head. For instance in column $5, R$ takes the value 1 for OECD and 0 for MENA. See Table 4 for the description of other variables. All regression include time dummy variables. * **, and *** indicate statistical significance at the 10,5 , and $1 \%$ level, respectively 
Table 11 Regional comparison of labor demand models: low-technology industries

\begin{tabular}{|c|c|c|c|c|c|c|c|}
\hline & \multicolumn{3}{|c|}{ Comparison with ASIA } & \multicolumn{4}{|c|}{ Comparison with ASIA } \\
\hline & ASIA-MENA & ASIA-SSA & ASIA-LAC & OECD-ASIA & OECD-MENA & OECD-SSA & OECD-LAC \\
\hline & 1 & 2 & 3 & 4 & 5 & 6 & 7 \\
\hline \multirow[t]{2}{*}{$\operatorname{Ln}(V)$} & 0.6013 & 0.5428 & 0.4683 & 0.6451 & 0.6394 & 0.5264 & 0.5100 \\
\hline & $(0.0290)^{* * *}$ & $(0.0375)^{* * *}$ & $(0.0389)^{* * *}$ & $(0.0186)^{* * *}$ & $(0.0219)^{* * *}$ & $(0.0276)^{* * *}$ & $(0.0299)^{* * *}$ \\
\hline \multirow[t]{2}{*}{$M /(M+Y)$} & -0.3726 & 0.2006 & 0.1651 & 0.2344 & -0.2831 & 0.1331 & 0.2436 \\
\hline & $(0.1029)^{* * *}$ & $(0.1153)^{*}$ & $(0.1894)$ & $(0.1204)^{*}$ & $(0.0783)^{* * *}$ & $(0.0854)$ & $(0.1471)^{*}$ \\
\hline \multirow[t]{2}{*}{$X / Y$} & 0.1551 & 0.0137 & -0.0365 & 0.0860 & 0.1720 & 0.0127 & -0.0611 \\
\hline & $(0.0379)^{* * *}$ & $(0.0289)$ & $(0.0776)$ & $(0.0354)^{* *}$ & $(0.0292)^{* * *}$ & $(0.0216)$ & $(0.0604)$ \\
\hline \multirow[t]{2}{*}{$\operatorname{Ln}(w)$} & -0.6222 & -0.5049 & -0.4778 & -0.6475 & -0.6515 & -0.4915 & -0.4895 \\
\hline & $(0.0237)^{* * *}$ & $(0.0287)^{* * *}$ & $(0.0282)^{* * *}$ & $(0.0170)^{* * *}$ & $(0.0181)^{* * *}$ & $(0.0214)^{* * *}$ & $(0.0219)^{* * *}$ \\
\hline \multirow[t]{2}{*}{$\operatorname{Ln}(w)^{*} S$} & 0.0872 & 0.1191 & 0.1624 & 0.1896 & 0.0907 & 0.1212 & 0.1758 \\
\hline & $(0.0088)^{* * *}$ & $(0.0114)^{* * *}$ & $(0.0120)^{* * *}$ & $(0.0071)^{* * *}$ & $(0.0068)^{* * *}$ & $(0.0085)^{* * *}$ & $(0.0093)^{* * *}$ \\
\hline \multirow[t]{2}{*}{$R^{*} \ln (V)$} & 0.0417 & 0.0918 & 0.1633 & 0.1153 & 0.1210 & 0.2264 & 0.2457 \\
\hline & $(0.0400)$ & $(0.0469)^{*}$ & $(0.0463)^{* * *}$ & $(0.0243)^{* * *}$ & $(0.0278)^{* * *}$ & $(0.0317)^{* * *}$ & $(0.0337)^{* * *}$ \\
\hline \multirow[t]{2}{*}{$R^{*} M /(M+\eta)$} & 0.6591 & 0.0331 & 0.1228 & -0.4596 & -0.0860 & -0.4604 & -0.6001 \\
\hline & $(0.1999)^{* * *}$ & $(0.2030)$ & $(0.2446)$ & $(0.1299)^{* * *}$ & $(0.0932)$ & $(0.0967)^{* * *}$ & $(0.1539)^{* * *}$ \\
\hline \multirow[t]{2}{*}{$R^{*} X Y$} & -0.0709 & 0.0733 & 0.1260 & 0.0778 & 0.0050 & 0.1583 & 0.2347 \\
\hline & $(0.0627)$ & $(0.0563)$ & $(0.0897)$ & $(0.0371)^{* *}$ & $(0.0316)$ & $(0.0244)^{* * *}$ & $(0.0614)^{* * *}$ \\
\hline \multirow[t]{2}{*}{$R^{*} \ln (W)$} & -0.0283 & -0.1413 & -0.1722 & -0.0900 & -0.1039 & -0.2533 & -0.2614 \\
\hline & $(0.0343)$ & $(0.0373)^{* * *}$ & $(0.0360)^{* * *}$ & $(0.0208)^{* * *}$ & $(0.0227)^{* * *}$ & $(0.0247)^{* * *}$ & $(0.0251)^{* * *}$ \\
\hline \multirow[t]{2}{*}{$R^{*} \ln (W)^{*} S$} & 0.0949 & 0.0650 & 0.0187 & -0.1390 & -0.0402 & -0.0712 & -0.1255 \\
\hline & $(0.0135)^{* * *}$ & $(0.0151)^{* * *}$ & $(0.0150)$ & $(0.0075)^{* * *}$ & $(0.0072)^{* * *}$ & $(0.0088)^{* * *}$ & $(0.0096)^{* * *}$ \\
\hline \multirow[t]{2}{*}{ _cons } & 1.9868 & 1.9666 & 2.5197 & 1.0328 & 1.1803 & 1.2093 & 1.3345 \\
\hline & $(0.3044)^{* * *}$ & $(0.3300)^{* * *}$ & $(0.3505)^{* * *}$ & $(0.2206)^{* * *}$ & $(0.2538)^{* * *}$ & $(0.2568)^{* * *}$ & $(0.2480)^{* * *}$ \\
\hline N & 2746 & 2272 & 2547 & 6275 & 5813 & 5339 & 5614 \\
\hline
\end{tabular}

Note: See Appendix A: Table 10 for notes 
Table 12 Regional comparison of labor demand models: medium-technology interactions

\begin{tabular}{|c|c|c|c|c|c|c|c|}
\hline & \multicolumn{3}{|c|}{ Comparison with ASIA } & \multicolumn{4}{|c|}{ Comparison with OECD } \\
\hline & ASIA-MENA & ASIA-SSA & ASIA-LAC & OECD-ASIA & OECD-MENA & OECD-SSA & OECD-LAC \\
\hline \multirow[t]{2}{*}{$\operatorname{Ln}(V)$} & 0.4404 & 0.4977 & 0.5341 & 0.3098 & 0.5313 & 0.4819 & 0.6106 \\
\hline & $(0.0271)^{* * *}$ & $(0.0413)^{* * *}$ & $(0.0431)^{* * *}$ & $(0.0233)^{* * *}$ & $(0.0195)^{* * *}$ & $(0.0315)^{* * *}$ & $(0.0342)^{* * *}$ \\
\hline \multirow[t]{2}{*}{$M /(M+\gamma)$} & -0.3306 & 0.5666 & -0.3482 & -0.4559 & -0.2402 & 0.5485 & -0.3069 \\
\hline & $(0.2227)$ & $(0.0978)^{* * *}$ & $(0.1619)^{* *}$ & $(0.1635)^{* * *}$ & $(0.1740)$ & $(0.0745)^{* * *}$ & $(0.1313)^{* *}$ \\
\hline \multirow[t]{2}{*}{$X Y$} & -0.0741 & -0.0225 & 0.0459 & 0.0349 & -0.0761 & -0.0329 & 0.0650 \\
\hline & $(0.0738)$ & $(0.1148)$ & $(0.0833)$ & $(0.0094)^{* * *}$ & $(0.0578)$ & $(0.0883)$ & $(0.0678)$ \\
\hline \multirow[t]{2}{*}{$\operatorname{Ln}(w)$} & -0.4172 & -0.6523 & -0.5511 & -0.4118 & -0.4347 & -0.6440 & -0.5783 \\
\hline & $(0.0188)^{* * *}$ & $(0.0238)^{* * *}$ & $(0.0325)^{* * *}$ & $(0.0175)^{* * *}$ & $(0.0146)^{* * *}$ & $(0.0182)^{* * *}$ & $(0.0263)^{* * *}$ \\
\hline \multirow[t]{2}{*}{$\operatorname{Ln}(w){ }^{*} S$} & 0.0416 & 0.0790 & 0.1800 & 0.0778 & 0.0458 & 0.0796 & 0.1954 \\
\hline & $(0.0045)^{* * *}$ & $(0.0070)^{* * *}$ & $(0.0133)^{* * *}$ & $(0.0076)^{* * *}$ & $(0.0035)^{* * *}$ & $(0.0054)^{* * *}$ & $(0.0107)^{* * *}$ \\
\hline \multirow[t]{2}{*}{$r^{*} \ln (V)$} & -0.1437 & -0.2218 & -0.2516 & 0.2833 & 0.0344 & 0.0929 & -0.0345 \\
\hline & $(0.0428)^{* * *}$ & $(0.0514)^{* * *}$ & $(0.0511)^{* * *}$ & $(0.0292)^{* * *}$ & $(0.0274)$ & $(0.0357)^{* * *}$ & $(0.0381)$ \\
\hline \multirow[t]{2}{*}{$r^{*} M /(M+Y)$} & -0.0628 & -0.9993 & -0.0731 & 0.2656 & -0.0158 & -0.7903 & 0.0621 \\
\hline & $(0.3214)$ & $(0.2380)^{* * *}$ & $(0.2525)$ & $(0.1783)$ & $(0.1906)$ & $(0.1022)^{* * *}$ & $(0.1475)$ \\
\hline \multirow[t]{2}{*}{$r^{*} X Y$} & 0.1079 & 0.0577 & -0.0115 & 0.0265 & 0.1429 & 0.0999 & 0.0028 \\
\hline & $(0.0750)$ & $(0.1155)$ & $(0.0840)$ & $(0.0289)$ & $(0.0653)^{* *}$ & $(0.0926)$ & $(0.0727)$ \\
\hline \multirow[t]{2}{*}{$r^{*} \ln (w)$} & 0.0092 & 0.2596 & 0.1542 & -0.1756 & -0.1562 & 0.0559 & -0.0096 \\
\hline & $(0.0311)$ & $(0.0334)^{* * *}$ & $(0.0386)^{* * *}$ & $(0.0217)^{* * *}$ & $(0.0206)^{* * *}$ & $(0.0225)^{* *}$ & $(0.0292)$ \\
\hline \multirow[t]{2}{*}{$r^{*} \ln (w)^{*} s$} & 0.0303 & -0.0084 & -0.1087 & 0.0033 & 0.0335 & 0.0006 & -0.1154 \\
\hline & $(0.0116)^{* * *}$ & $(0.0122)$ & $(0.0160)^{* * *}$ & $(0.0085)$ & $(0.0053)^{* * *}$ & $(0.0065)$ & $(0.0113)^{* * *}$ \\
\hline \multirow[t]{2}{*}{ _cons } & 5.2281 & 6.2559 & 5.4769 & 3.4292 & 2.8422 & 2.9813 & 2.6406 \\
\hline & $(0.3893)^{* * *}$ & $(0.4487)^{* * *}$ & $(0.4203)^{* * *}$ & $(0.2594)^{* * *}$ & $(0.2891)^{* * *}$ & $(0.2947)^{* * *}$ & $(0.2748)^{* * *}$ \\
\hline N & 2977 & 2164 & 2493 & 6957 & 6734 & 5921 & 6,250 \\
\hline
\end{tabular}

Note: See Appendix A: Table 10 for notes 
Table 13 Regional comparison of labor demand models: high-technology interactions

\begin{tabular}{|c|c|c|c|c|c|}
\hline & \multicolumn{2}{|c|}{ Comparison with ASIA } & \multicolumn{3}{|c|}{ Comparison with OECD } \\
\hline & ASIA-MENA & ASIA-LAC & OECD-ASIA & OECD-MENA & OECD-LAC \\
\hline \multirow[t]{2}{*}{$\operatorname{Ln}(V)$} & 0.5958 & 0.3924 & 0.4011 & 0.6880 & 0.4369 \\
\hline & $(0.0356)^{* * *}$ & $(0.0529)^{* * *}$ & $(0.0205)^{* * *}$ & $(0.0220)^{* * *}$ & $(0.0362)^{* * *}$ \\
\hline \multirow[t]{2}{*}{$M /(M+Y)$} & -0.1863 & -0.4486 & 0.2039 & -0.1864 & -0.3298 \\
\hline & $(0.1886)$ & $(0.2695)^{*}$ & $(0.1278)$ & $(0.1300)$ & $(0.1859)^{*}$ \\
\hline \multirow[t]{2}{*}{$X Y$} & -0.1293 & 0.0825 & -0.0057 & -0.1251 & 0.0814 \\
\hline & $(0.0953)$ & $(0.0706)$ & $(0.0110)$ & $(0.0657)^{*}$ & $(0.0487)^{*}$ \\
\hline \multirow[t]{2}{*}{$\operatorname{Ln}(w)$} & -0.6018 & -0.4708 & -0.4437 & -0.6356 & -0.4827 \\
\hline & $(0.0271)^{* * *}$ & $(0.0485)^{* * *}$ & $(0.0142)^{* * *}$ & $(0.0183)^{* * *}$ & $(0.0334)^{* * *}$ \\
\hline \multirow[t]{2}{*}{$\operatorname{Ln}(w)^{*} S$} & 0.1207 & 0.0720 & 0.0488 & 0.1300 & 0.0816 \\
\hline & $(0.0101)^{* * *}$ & $(0.0140)^{* * *}$ & $(0.0051)^{* * *}$ & $(0.0069)^{* * *}$ & $(0.0097)^{* * *}$ \\
\hline \multirow[t]{2}{*}{$r^{*} \ln (V)$} & -0.2587 & -0.0296 & 0.2277 & -0.0771 & 0.1865 \\
\hline & $(0.0434)^{* * *}$ & $(0.0592)$ & $(0.0257)^{* * *}$ & $(0.0265)^{* * *}$ & $(0.0389)^{* * *}$ \\
\hline \multirow[t]{2}{*}{$r^{*} M /(M+Y)$} & 0.3819 & 0.6262 & -0.0517 & 0.3236 & -0.0824 \\
\hline & $(0.2601)$ & $(0.3116)^{* *}$ & $(0.1430)$ & $(0.1440)^{* *}$ & $(0.0492)^{*}$ \\
\hline \multirow[t]{2}{*}{$r^{*} X Y$} & 0.1283 & -0.0842 & 0.0040 & 0.1243 & 0.4767 \\
\hline & $(0.0966)$ & $(0.0719)$ & $(0.0138)$ & $(0.0662)^{*}$ & $(0.1936)^{* *}$ \\
\hline \multirow[t]{2}{*}{$r^{*} \ln (w)$} & 0.1534 & 0.0303 & -0.2416 & -0.0446 & -0.1990 \\
\hline & $(0.0338)^{* * *}$ & $(0.0515)$ & $(0.0195)^{* * *}$ & $(0.0224)^{* *}$ & $(0.0353)^{* * *}$ \\
\hline \multirow[t]{2}{*}{$r^{*} \ln (w)^{*} s$} & -0.0767 & -0.0266 & 0.0459 & -0.0370 & 0.0121 \\
\hline & $(0.0122)^{* * *}$ & $(0.0153)^{*}$ & $(0.0067)^{* * *}$ & $(0.0080)^{* * *}$ & $(0.0103)$ \\
\hline \multirow[t]{2}{*}{ _cons } & 4.7270 & 5.3752 & 3.2307 & 2.5950 & 2.8839 \\
\hline & $(0.4310)^{* * *}$ & $(0.4209)^{* * *}$ & $(0.2288)^{* * *}$ & $(0.2335)^{* * *}$ & $(0.2131)^{* * *}$ \\
\hline$N$ & 2800 & 2682 & 7327 & 6493 & 6375 \\
\hline
\end{tabular}

Note: See Appendix A: Table 10 for notes 
Appendix B: First stage regression results

Table 14 First Stage Regression Results for ASIA Corresponding to Table 4

\begin{tabular}{|c|c|c|c|c|}
\hline & Value added & Wage rate & Import penetration & Export-output \\
\hline \multirow[t]{2}{*}{$\mathrm{EXI}_{i j t}$} & -0.2344 & 0.1321 & 0.0771 & 0.0329 \\
\hline & 0.0468 & 0.0376 & 0.0075 & 0.0254 \\
\hline \multirow[t]{2}{*}{$\mathrm{PP}_{i j t}$} & -0.0024 & -0.0073 & -0.0001 & -0.0001 \\
\hline & 0.0006 & 0.0005 & 0.0001 & 0.0003 \\
\hline \multirow[t]{2}{*}{$\mathrm{REXI}_{i j t}^{\mathrm{US}}$} & -0.3890 & -0.8549 & -0.0297 & -0.0513 \\
\hline & 0.0175 & 0.0140 & 0.0028 & 0.0095 \\
\hline \multirow[t]{2}{*}{ REXIUS -squared } & 0.0057 & 0.0048 & 0.0007 & -0.0003 \\
\hline & 0.0012 & 0.0010 & 0.0002 & 0.0007 \\
\hline \multirow[t]{2}{*}{$\mathrm{GDPl}_{i j t}$} & -0.0073 & 0.0012 & -0.0007 & -0.0009 \\
\hline & 0.0008 & 0.0006 & 0.0001 & 0.0004 \\
\hline \multirow[t]{2}{*}{$\operatorname{Ln}(w)$ - two-digit SIC } & 0.2787 & 0.0824 & -0.0005 & -0.0189 \\
\hline & 0.0181 & 0.0145 & 0.0029 & 0.0098 \\
\hline \multirow[t]{2}{*}{ GDPI-domestic } & 0.0133 & 0.0117 & 0.0006 & 0.0008 \\
\hline & 0.0007 & 0.0006 & 0.0001 & 0.0004 \\
\hline F statistic & 108.7 & 716.34 & 18.81 & 8.46 \\
\hline
\end{tabular}

Note: $\mathrm{EXI}_{i j t}$ is a weighted average exchange rate index of import supplier countries, $\mathrm{PPI}_{i j t}$ is a weighted average industryspecific price index of import source countries, REXI $\left.\right|_{i j t} ^{U S}$ is weighted average real exchange rate index for export destination countries, GDPI ${ }_{i j t}$ is the aggregate GDP index of export destination countries applicable to industry $j$ of an exporting country, In (w)- two-digit SIC is the log of wage rate at the two-digit SIC level, and GDPI-domestic is GDP index at the country level. Robust standard errors are in parenthesis

Table 15 First stage regression results for SSA corresponding to Table 4

\begin{tabular}{|c|c|c|c|c|}
\hline & Value added & Wage rate & Import penetration & Export-output \\
\hline \multirow[t]{2}{*}{$\mathrm{EXI}_{i j t}$} & 0.3426 & 0.0741 & -0.0026 & -0.0182 \\
\hline & $(0.0500)$ & $(0.0676)$ & $(0.0166)$ & $(0.0394)$ \\
\hline \multirow[t]{2}{*}{$\mathrm{PP}_{i j t}$} & -0.0058 & -0.0073 & -0.0006 & -0.0002 \\
\hline & $(0.0011)$ & $(0.0015)$ & $(0.0004)$ & $(0.0008)$ \\
\hline \multirow[t]{2}{*}{$\operatorname{REXI}_{i j t}^{U S}$} & -0.1949 & -0.7543 & -0.0315 & -0.0574 \\
\hline & $(0.0272)$ & $(0.0368)$ & $(0.0090)$ & $(0.0214)$ \\
\hline \multirow[t]{2}{*}{ REXI Ijt $_{i j t}^{\text {SS }}$-squared } & -0.0301 & 0.0044 & 0.0008 & 0.0010 \\
\hline & $(0.0039)$ & $(0.0053)$ & $(0.0013)$ & $(0.0031)$ \\
\hline \multirow[t]{2}{*}{$\mathrm{GDPI}_{i j t}$} & -0.0028 & 0.0004 & 0.0014 & -0.0005 \\
\hline & $(0.0010)$ & $(0.0014)$ & $(0.0003)$ & $(0.0008)$ \\
\hline \multirow[t]{2}{*}{ Ln (w)- two-digit SIC } & 0.0779 & -0.1010 & 0.0346 & -0.0061 \\
\hline & $(0.0371)$ & $(0.0502)$ & $(0.0123)$ & $(0.0292)$ \\
\hline \multirow[t]{2}{*}{ GDPI-domestic } & 0.0098 & -0.0082 & 0.0013 & 0.0013 \\
\hline & $(0.0011)$ & $(0.0015)$ & $(0.0004)$ & $(0.0009)$ \\
\hline F statistic & 53.76 & 89.23 & 17.98 & 2.09 \\
\hline
\end{tabular}

Note: See notes to Appendix B: Table 14 
Table 16 First stage regression results for LAC corresponding to Table 4

\begin{tabular}{|c|c|c|c|c|}
\hline & Value added & Wage rate & Import penetration & Export-output \\
\hline \multirow[t]{2}{*}{$\mathrm{EXI}_{\mathrm{ijt}}$} & -0.0815 & -0.0554 & -0.0028 & 0.0362 \\
\hline & 0.0334 & 0.0330 & 0.0085 & 0.0260 \\
\hline \multirow[t]{2}{*}{$\mathrm{PP}_{i j t}$} & -0.0002 & -0.0086 & -0.0003 & -0.0005 \\
\hline & 0.0005 & 0.0005 & 0.0001 & 0.0004 \\
\hline \multirow[t]{2}{*}{$\operatorname{REXI}_{i j t}^{\mathrm{US}}$} & -0.0780 & -0.6938 & -0.0640 & -0.0523 \\
\hline & 0.0124 & 0.0123 & 0.0031 & 0.0097 \\
\hline \multirow[t]{2}{*}{ REXI Ijt $_{\text {US }}$-squared } & -0.0177 & -0.0154 & 0.0030 & 0.0024 \\
\hline & 0.0017 & 0.0017 & 0.0004 & 0.0013 \\
\hline \multirow[t]{2}{*}{$\mathrm{GDPI}_{i j t}$} & -0.0016 & -0.0011 & 0.0003 & 0.0017 \\
\hline & 0.0010 & 0.0009 & 0.0002 & 0.0007 \\
\hline \multirow[t]{2}{*}{ Ln (w)- two-digit SIC } & -0.1089 & -0.0095 & -0.0149 & -0.0138 \\
\hline & 0.0242 & 0.0239 & 0.0061 & 0.0188 \\
\hline \multirow[t]{2}{*}{ GDPI-domestic } & 0.0210 & 0.0378 & 0.0011 & 0.0025 \\
\hline & 0.0022 & 0.0022 & 0.0006 & 0.0017 \\
\hline F statistic & 53.98 & 293.27 & 31.95 & 3.98 \\
\hline
\end{tabular}

Note: See notes to Appendix B: Table 14

Table 17 First stage regression results for OECD corresponding to Table 4

\begin{tabular}{|c|c|c|c|c|}
\hline & Value added & Wage rate & Import penetration & Export-output \\
\hline \multirow[t]{2}{*}{$\mathrm{EXI}_{i j t}$} & -0.1835 & -0.0197 & 0.0155 & 0.0443 \\
\hline & 0.0195 & 0.0142 & 0.0066 & 0.0206 \\
\hline \multirow[t]{2}{*}{$\mathrm{PP}_{i j t}$} & -0.0056 & -0.0118 & 0.0000 & -0.0005 \\
\hline & 0.0002 & 0.0002 & 0.0001 & 0.0002 \\
\hline \multirow[t]{2}{*}{$\operatorname{REXI}_{i j t}^{\mathrm{US}}$} & -0.3381 & -0.8440 & -0.0367 & -0.1030 \\
\hline & 0.0054 & 0.0039 & 0.0018 & 0.0057 \\
\hline \multirow[t]{2}{*}{ REXI Ijt $_{i j t}^{\text {SS }}$-squared } & 0.0063 & 0.0193 & 0.0011 & 0.0040 \\
\hline & 0.0010 & 0.0007 & 0.0003 & 0.0010 \\
\hline \multirow[t]{2}{*}{$\mathrm{GDP}_{i j t}$} & -0.0057 & -0.0009 & 0.0005 & 0.0005 \\
\hline & 0.0003 & 0.0002 & 0.0001 & 0.0004 \\
\hline \multirow[t]{2}{*}{ Ln (w)- two-digit SIC } & 0.0842 & 0.0272 & -0.0197 & -0.0333 \\
\hline & 0.0079 & 0.0058 & 0.0027 & 0.0084 \\
\hline \multirow[t]{2}{*}{ GDPI-domestic } & 0.0140 & 0.0140 & 0.0004 & -0.0003 \\
\hline & 0.0003 & 0.0002 & 0.0001 & 0.0004 \\
\hline F statistic & 366.11 & 2974 & 85.45 & 40.67 \\
\hline
\end{tabular}

Note: See notes to Appendix B: Table 14 
Table 18 First stage regression results for CEE corresponding to Table 4

\begin{tabular}{|c|c|c|c|c|}
\hline & Value added & Wage rate & Import penetration & Export-output \\
\hline \multirow[t]{2}{*}{$\mathrm{EXI}_{i j t}$} & 0.1079 & 0.2663 & 0.0136 & -0.0074 \\
\hline & 0.0314 & 0.0285 & 0.0060 & 0.0239 \\
\hline \multirow[t]{2}{*}{$\mathrm{PP}_{i j t}$} & -0.0016 & -0.0045 & -0.0003 & -0.0006 \\
\hline & 0.0004 & 0.0004 & 0.0001 & 0.0003 \\
\hline \multirow[t]{2}{*}{$\mathrm{REXI}_{i j t}^{\mathrm{US}}$} & -0.2813 & -0.6260 & -0.0306 & -0.0670 \\
\hline & 0.0066 & 0.0060 & 0.0013 & 0.0050 \\
\hline \multirow[t]{2}{*}{ REXI US -squared } & -0.0228 & -0.0454 & -0.0037 & -0.0058 \\
\hline & 0.0020 & 0.0018 & 0.0004 & 0.0015 \\
\hline \multirow[t]{2}{*}{$\mathrm{GDPl}_{i j t}$} & 0.0016 & 0.0039 & 0.0005 & 0.0000 \\
\hline & 0.0007 & 0.0007 & 0.0001 & 0.0005 \\
\hline \multirow[t]{2}{*}{$\operatorname{Ln}(w)$ - two-digit SIC } & 0.0521 & 0.0043 & -0.0122 & -0.0223 \\
\hline & 0.0171 & 0.0155 & 0.0033 & 0.0130 \\
\hline \multirow[t]{2}{*}{ GDPI-domestic } & 0.0047 & 0.0060 & -0.0001 & -0.0002 \\
\hline & 0.0003 & 0.0003 & 0.0001 & 0.0002 \\
\hline F statistic & 210.77 & 774.19 & 36.84 & 10.7 \\
\hline
\end{tabular}

Note: See notes to Appendix B: Table 14

Table 19 First stage regression results for MENA corresponding to Table 4

\begin{tabular}{|c|c|c|c|c|}
\hline & Value added & Wage rate & Import penetration & Export-output \\
\hline \multirow[t]{2}{*}{$\mathrm{EXI}_{i j t}$} & -0.1983 & -0.0764 & 0.0321 & 0.0317 \\
\hline & 0.0329 & 0.0311 & 0.0076 & 0.0181 \\
\hline \multirow[t]{2}{*}{$\mathrm{PP}_{i j t}$} & -0.0028 & -0.0079 & -0.0002 & -0.0007 \\
\hline & 0.0006 & 0.0006 & 0.0001 & 0.0003 \\
\hline \multirow[t]{2}{*}{$\operatorname{REXI}_{i j t}^{\mathrm{US}}$} & -0.2730 & -0.7793 & -0.0182 & -0.0407 \\
\hline & 0.0106 & 0.0101 & 0.0024 & 0.0059 \\
\hline \multirow[t]{2}{*}{ REXI Ijt $_{i j t}^{\text {SS }}$-squared } & 0.0074 & 0.0231 & 0.0007 & 0.0011 \\
\hline & 0.0008 & 0.0008 & 0.0002 & 0.0004 \\
\hline \multirow[t]{2}{*}{$\mathrm{GDPI}_{i j t}$} & 0.0026 & 0.0026 & 0.0001 & -0.0004 \\
\hline & 0.0009 & 0.0009 & 0.0002 & 0.0005 \\
\hline \multirow[t]{2}{*}{ Ln (w)- two-digit SIC } & 0.0452 & 0.0030 & -0.0111 & 0.0080 \\
\hline & 0.0254 & 0.0240 & 0.0058 & 0.0140 \\
\hline \multirow[t]{2}{*}{ GDPI-domestic } & 0.0007 & -0.0002 & 0.0006 & 0.0027 \\
\hline & 0.0013 & 0.0013 & 0.0003 & 0.0007 \\
\hline F statistic & 154.17 & 456.14 & 11.36 & 4.73 \\
\hline
\end{tabular}

Note: See notes to Appendix B: Table 14 


\section{Appendix C}

Table $\mathbf{2 0}$ List of sample countries by region

\begin{tabular}{|c|c|c|c|c|c|}
\hline $\begin{array}{l}\text { Asia and } \\
\text { Pacific }\end{array}$ & $\begin{array}{l}\text { Central and } \\
\text { Eastern Europe }\end{array}$ & $\begin{array}{l}\text { Middle East and } \\
\text { North Africa }\end{array}$ & $\begin{array}{l}\text { Sub-Saharan } \\
\text { Africa }\end{array}$ & $\begin{array}{l}\text { Latin America } \\
\text { and Caribbean }\end{array}$ & OECD \\
\hline China & Albania & Egypt & Botswana & Argentina & Australia \\
\hline Fiji & Azerbaijan & Iran & Eritrea & Bahamas & Austria \\
\hline Hong Kong & Belarus & Jordan & Ethiopia & Bolivia & Belgium \\
\hline Indonesia & Bulgaria & Kuwait & Madagascar & Brazil & Denmark \\
\hline South Korea & Cyprus & Morocco & Malawi & Chile & Finland \\
\hline Macao, China & Estonia & Oman & Mauritius & Colombia & Germany \\
\hline Malaysia & Georgia & Qatar & Senegal & Ecuador & Greece \\
\hline Mongolia & Kyrgyz Republic & Israel & South Africa & Mexico & Hungary \\
\hline Philippines & Latvia & & & Paraguay & Ireland \\
\hline Singapore & Lithuania & & & Peru & Japan \\
\hline \multirow[t]{7}{*}{ Sri Lanka } & Moldova & & & & Luxembourg \\
\hline & Poland & & & & Malta \\
\hline & Romania & & & & Netherlands \\
\hline & Russian Federation & & & & New Zealand \\
\hline & Slovak Republic & & & & Portugal \\
\hline & Slovenia & & & & Spain \\
\hline & & & & & Sweden \\
\hline
\end{tabular}

\section{Competing interests}

The IZA Journal of Labor \& Development is committed to the IZA Guiding Principles of Research Integrity. The authors declare that they have observed these principles.

\section{Acknowledgements}

We thank Berhanu Abegaz and Peter McHenry for their comments and suggestions. We are also grateful to the important comments provided by a referee and the editor of IZA-JOLD that helped us improve the paper. Responsible editor: David Lam

\section{Author details}

${ }^{1}$ The College of William and Mary Williamsburg, Virginia, USA. ${ }^{2}$ UNDP (United Nation Development Programme), New York, USA.

Received: 25 August 2015 Accepted: 15 January 2016 Bt?

\section{References}

Attanasio O, Goldberg PK, Pavcnik N (2004) Trade reforms and wage inequality in Colombia. J Dev Econ 74:331-366

Autor D, Dron D, Hanson G (2013) The China syndrome: local labor market effects of import competition in the United States. Am Econ Rev 103(6):2121-68

Bernard B, Jensen JB (1999) Exceptional export performance: cause, effects, or both? J Int Econ 47:1,1-25

Bernard A, Eaton J, Jensen JB, Kortum S (2003) Plants and productivity in international trade. Am Econ Rev 94:1265-1290

Bernard BA, Redding SJ, Schott PK (2010) Multiple-product firms and product switching. Am Econ Rev 100(1):70-97

Bhalotra S (1998) The puzzle of jobless growth in Indian manufacturing. Oxf Bull Econ Stat 60:1,5-32

Botero CJ, Djankov S, La Porta R, Lopez-De-Silanes F, Shleiefer A (2004) The regulation of labor. Q J Econ 119(4):1339-1382

Caballero R, Hammour M (1997) Jobless growth: appropriability, factor-substitution and unemployment, NBER Working Paper No. 6221, National Bureau of Economic Research.

Dauth W, Suedekum J, Findeisen S (2014) The rise of the East and the Far East: German labor markets and trade integration. J Eur Econ Assoc 12(6):1643-75

Davidson C, Matusz SJ, Shevchenko A (2008) Globalization and firm level adjustment with imperfect labor markets.

J Int Econ 75:295-309

Davis D, Harrigan J (2011) Good jobs, bad jobs, and trade liberalization. J Int Econ 84:26-36 
Dutt P, Mitra D, Ranjan P (2009) International trade and unemployment: theory and cross-national evidence. $J$ Int Econ 78:32-44

Egger H, Kreickemeier U (2009) Firm heterogeneity and the labor market effects of trade liberalization. Int Econ Rev 50(1):187-216

Fallon P, Lucas R (1993) Job security regulations and the dynamic demand for industrial labor in India and Zimbabwe. J Dev Econ 40:241-275

Felbermayr G, Prat J, Schmerer H-J (2011a) Globalization and labor market outcomes: wage bargaining, search frictions, and firm heterogeneity. J Econ Theory 146:39-73

Felbermayr G, Prat J, Schmerer H-J (2011b) Trade and unemployment: what do the data say. Eur Econ Rev 55:741-758

Freeman R (2010) Labor regulations, unions, and social protection in developing countries: market distortions or efficient institutions? vol 5, Handbook of development economics. Elsevier, Amsterdam, pp 4657-4702

Goldberg P, Pavcnik N (2003) The response of the informal sector to trade liberalization. J Dev Econ 72:463-496

Goldberg P, Pavcnik N (2007) Distributional effects of globalization in developing countries. J Econ Lit XLV:39-82

Goldberg KP, Khandelwall AK, Pavcnik N, Topalova P (2010) Multiproduct firms and product turnover in the developing world: evidence from India. Rev Econ Stat 92(4):1042-1049

Greenaway D, Hine R, Wright P (1999) An empirical assessment of the impact of trade on employment in the United Kingdom. Eur J Polit Econ 15:485-500

Haltiwanger J, Scarpetta S, Schweiger H (2008) Assessing job flows across countries: the role of industry, firm size and regulations, NBER Working Paper No. 13920, National Bureau of Economic Research.

Hamermesh DS (1993) Labor demand. Princeton University Press, Princeton

Hasan R, Mitra D, Ramaswamy KV (2007) Trade reforms, labor regulations, and labor-demand elasticities: empirical evidence from India. Rev Econ Stat 89(3):466-481

Hasan R, Mitra D, Ranjan P, Ahsan R (2012) Trade liberalization and unemployment: theory and evidence from India. J Dev Econ 97:269-280

Hatzichronoglou T (1997) Revision of the high-technology sector and product classification. OECD Science, Technology and Industry Working Paper 1997/02, Paris

Hausmann R, Hwang J, Rodrik D (2007) What you export matters. J Econ Growth 12:1,1-25

Helpman E, Itskhoki O, Redding S (2010) Inequality and unemployment in a global economy. Econometrica 78(4):1239-1283

Herrendorf B, Rogerson R, Valentinyi A (2013) Growth and structural transformation, NBER Working Paper No. 18996, National Bureau of Economic Research.

Imbs J, Wacziarg R (2003) Stages of diversification. Am Econ Rev 93:1,63-86

IȘcan T (1998) Trade liberalization and productivity: a panel study of the Mexican manufacturing industry. J Dev Stud 34(5):123-148

James B, and Olken B (2005) The anatomy of start-stop growth, NBER Working Paper No. 11528, National Bureau of Economic Research.

Jenkins R (2008) Trade, technology and employment in South Africa. J Dev Stud 44:1,60-79

Jonsson G, Subramanian A (2001) Dynamic gains from trade: evidence from South Africa. IMF Staff Pap 48(1):197-224

Kapsos S (2005) The employment intensity of growth: trends and macroeconomic determinants, Employment Strategy Papers 2005/12, International Labor Organization.

Kim E (2000) Trade liberalization and productivity growth in Korean manufacturing industries: prices, protection, market power, and scale efficiency. J Dev Econ 62:55-83

Melitz M (2003) The impact of trade on intra-industry reallocation and aggregate industry productivity. Econometrica $71(6): 1695-1725$

Menezes-Filho NA, Muendler M (2011) Labor reallocation in response to trade reform, NBER Working Paper No. 17372, National Bureau of Economic Research.

Pavcnik N (2002) Trade liberalization, exit, and productivity improvements: evidence from Chilean plants. Rev Econ Stud 69:245-276

Revenga A (1992) Exporting jobs?: the impact of import competition on employment and wages in US manufacturing. Q J Econ 107(1):255-284

Revenga A (1997) Employment and wage effects of trade liberalization: the case of Mexican manufacturing. J Labor Econ 15(S3):S20-S43

Rodrik D (1997) Has globalization gone too far? Institute for International Economics, Washington, DC Sachs DJ, Shatz HJ, Deardorff A, Hall RE (1994) Trade and jobs in U.S. manufacturing. Brook Pap Econ Act 1994(1):1-84

Schor A (2004) Heterogeneous productivity reponse to tariff reduction. Evidence from Brazilian manufacturing firms. J Dev Econ 75:373-396

Slaughter M (2001) International trade and labor-demand elasticities. J Int Econ 54:27-56

Söderbom M, Teal F (2000) Skills, investment and exports from manufacturing firms in Africa. J Dev Stud 37(2):13-43

Wacziarg R, Wallack JS (2004) Trade liberalization and intersectoral labor movements. J Int Econ 64:411-439

World Bank (2012) Jobs, World Development Report 2013. International Bank of Reconstruction and Development, Washington, DC 